\title{
sciendo
}

\section{EFFECTS OF ADDITION OF EXOGENOUS FIBROLYTIC ENZYMES ON DIGESTIBILITY AND MILK AND MEAT PRODUCTION - A SYSTEMATIC REVIEW}

Deli Nazmín Tirado-González ${ }^{1}$, Gustavo Tirado-Estrada² ${ }^{2}$ Luis Alberto Miranda-Romero³, Rodolfo Ramírez-Valverde ${ }^{3}$, Sergio Ernesto Medina-Cuéllar ${ }^{4}$, Abdelfattah Z.M. Salem ${ }^{5 *}$

\author{
${ }^{1}$ Instituto Nacional de Investigaciones Forestales Agrícolas y Pecuarias (INIFAP)/Centro Nacional \\ de Investigación Disciplinaria AF (CENID AF), Km. 8.5 Carr. Ojuelos-Lagos de Moreno, \\ Ojuelos de Jalisco, Jalisco, México, C.P. 47540 \\ ${ }^{2}$ División de Estudios de Posgrado e Investigación (DEPI), Instituto Tecnológico El Llano \\ Aguascalientes (ITEL)/Tecnológico Nacional de México (TecNM), Km. 18.5 Carr. \\ Aguascalientes-S.L.P., El Llano, Ags., México, C.P. 20330 \\ ${ }^{3}$ Departamento de Zootecnia, Posgrado en Producción Animal (PPA), Universidad Autónoma \\ Chapingo, Km. 38.5 Carr. México-Texcoco, Estado de México, México, C.P. 56230 \\ ${ }^{4}$ Departamento de Ciencias y Artes, Universidad de Guanajuato, Campus Salamanca, Km. 3.5+1.8 \\ Carr. Salamanca-Valle de Santiago, Guanajuato, México, C.P. 36885 \\ ${ }^{5}$ Facultad de Medicina Veterinaria y Zootecnia, Universidad Autónoma del Estado de México, Toluca, \\ Estado de México, C.P. 50130 \\ •Corresponding author: salem@uaemex.mx; asalem70@yahoo.com
}

\begin{abstract}
Exogenous fibrolytic enzymes (EFE) added to the ruminant diet can increase fiber digestibility and production efficiency. A systematic review was conducted to understand the interactions between EFE and diet on digestibility and animal performance. The database included variables from 384 experiments with EFE and 264 controls from 85 papers published since 2000 (classification criteria: 1) type of study (in vitro, in situ, in vivo), 2) type of ruminants (sheep, buffaloes, goats, beef and dairy cattle), 3) primary EFE activity (cellulases (Cel) or xylanases (Xyl)), 4) forage proportion (FP), 5) type of plant (TP: legumes or grasses), 6) number of ingredients in diets, and 7) application time (AT)). In over $52.85 \%$ of cases, EFE improved the degradability of dry matter (DMD), neutral and acid detergent fiber (NDFD and ADFD), in vitro gas production (GP), volatile fatty acids (VFA), the acetate: propionate ratio (A:P ratio), protein and fat milk, milk yield and average daily gain (ADG) (by 7.78-21.85\%). Cel improved organic matter degradability (OMD), GP, VFA, milk yield, and milk protein and fat content. EFE in FP $\geq \mathbf{4 0 \%}$ diets enhanced the ADG, and in grassbased diets increased the dry matter intake (DMI). The AT of EFE affected the DMD, NDFD, and ADFD. Significant correlations were found between the improvements of NDFD or ADFD with DMD ( $r>0.59)$, milk yield $(r=0.64)$, and ADG $(r=0.59)$. In conclusion, many factors interact with EFE supplementation effects, but EFE consistently enhanced the DMD, NDFD, and ADFD of ruminant diets, which are related to improvements in productive performance.
\end{abstract}

Key words: exogenous enzymes, forage proportion, ruminal dynamics, animal performance, systematic review 
The inclusion of agricultural wastes as energy sources in livestock production can help to reduce the environmental pollution derived from emissions of greenhouse gases associated with extensive grain production (Knapp et al., 2014; Kholif et al., 2017). Straw is an agricultural by-product used to feed animals, but the high cell wall content can limit ruminal degradation by enzymes and microorganisms, and nutrient availability (Kholif et al., 2014; Gado et al., 2017), because of the barely hydrolyzable $\beta-1,4$ bonds that link the monomers that form polymers of cellulose and hemicellulose, and lignin that cross-links polysaccharides and strengthens the cell wall during plant maturation (Hatfield and Fukushima, 2005; Jung et al., $2006 \mathrm{a}, \mathrm{b})$.

Cellulases (endo- $\beta$-glucanases, exo- $\beta$-glucanases or cellobiohydrolases and $\beta$-glucosidases) and xylanases (arabinofurosidases, acetylxylan esterases, glucuronidases, $\beta$-xylosidases, and endo- $\beta$-xylanases) are enzymes that break the links in cellulose and hemicellulose to release soluble sugars (Tirado-González et al., 2016). These enzymes hydrolyze components of the cell wall to produce substrates that favor selected populations of microorganisms (Nsereko et al., 2002; Salem et al., 2015 a).

Supplementing the ruminant diet with EFE can increase the availability of energy in fibrous feed by improving ruminal fermentation and fiber and DM degradability (Alsersy et al., 2015; Salem et al., 2013, 2015 b; Vallejo et al., 2016 b), improving characteristics of productive animal performance (Tirado-González et al., 2018) such as the composition and production of milk (Gado et al., 2014; Morsy et al., 2016), average daily gain (ADG) (López-Aguirre et al., 2016 a), and feed conversion (FC) (Salem et al., 2013), and also reduces methane production (Beauchemin et al., 2008; Elghandour et al., 2016; Hernández et al., 2017 a, b) . However, responses can vary because many factors interact with the EFE effects (Tirado-González et al., 2018), including the type of enzymes in EFE products that have different specific domains, temperature, $\mathrm{pH}$, active site affinity, isoelectric points, molecular weights, spectral characteristics and sugar content (Zhou et al., 2007; Alsersy et al., 2015; Vallejo et al., 2016 b), the type of diet (Elghandour et al., 2016), the dose (Salem et al., 2015 b; López-Aguirre et al., 2016 b; Vallejo et al., 2016 b), and the application time (Wang et al., 2012).

Using previously published data collected in in vitro, in situ and in vivo studies, the present study aimed to statistically relate differences in the type of diet to the overall effects of using EFE on digestibility, fermentation patterns and milk and meat production.

\section{Material and methods}

\section{Sampling method}

A database was generated by extracting information from a non-recurring list of peer-reviewed articles published between 2000 to 2013, obtained by a literature search of Google Scholar (http://www.scholar.google.com/) and CAB Abstracts 
(http://www.cabi.org/) using the following combinations of words: 1) "fibrolytic enzymes"; 2) "cellulases xylanases ruminant"; 3) "exogenous fibrolytic enzymes ruminant"; 4) "exogenous fibrolytic enzymes"; and 5) "exogenous enzymes ruminant", according to the procedures of Arriola et al. (2017) and Tirado-González et al. (2018). Criteria for identification, screening, election, and inclusion of cites were made according to the PRISMA flow of Mohar et al. (2009).

\section{Articles included}

The search procedure identified 423 non-recurring items from Google Scholar, and 226 articles from CAB Abstracts. Additionally, 50 articles published from 2013 to 2019 were selected from a random searching in Google Scholar and were also included for comparison.

\section{Exclusion criteria}

The 226 articles from CAB Abstracts gave a representative sample of all articles published from 2000 to 2013 presented in Google Scholar. Therefore, studies were excluded from the list of 226 articles (from CAB Abstracts) if it was not possible to separate the EFE effect from other factors, or if they did not address variables related to fermentation patterns, in vivo, in situ, or in vitro digestibility, or productive animal performance. Reviews or longitudinal studies and manuscripts written in languages other than English, Spanish or Portuguese were also excluded. Statistical analysis was performed in 85 non-recurrent items from the original list of articles (see Appendix A1), discussion was made using additional 44 articles.

\section{Coding of data and study factors}

Experiment definition

Articles included treatments nested into experiments that were individually coded as a record; therefore, each experiment contained at least two treatments (control without EFE supplementation, and treatments with EFE supplementation).

\section{EFE/control differences}

Treatment means were expressed relative to the control by dividing each mean by their respective control (C: without $\mathrm{EFE} ; \mathrm{EFE} / \mathrm{C})$. The percentage of change due to EFE effects was also calculated $(\%$ changes $=(\mathrm{EFE} / \mathrm{C}-1) * 100)$.

\section{Classification of the experiments}

According to the statistical analyses reported in each paper, means were also classified and grouped as statistically significant (Dif; differences at $\mathrm{P}<0.05$ and $\mathrm{P}>0.05$ ) positive or negative effects (Ef) related to the use of EFE.

Data were classified and grouped according to: 1) type of study: in situ, in vitro, or in vivo; 2) animal species used in the experiment: sheep, goats, lactating dairy cows, beef cattle, or buffaloes; 3) primary forage in the diet: grasses or legumes; 4 ) dietary forage proportion (FP): $<50$ and $\geq 50 \%$; 5) primary supplemented EA: no enzyme, cellulases (different types of $\beta$-glucanases), or xylanases; 6 ) number of ingredients included in experimental diets; and 7) application time (AT) of EFE to 
the feed or diet (added to feed in a liquid form for a pre-treatment or provided as a powder in the concentrate or mixed with the diet): $<1 \mathrm{~h}, 1-24 \mathrm{~h}, 25 \mathrm{~h}-10 \mathrm{~d},>10 \mathrm{~d}$ prior to evaluation.

\section{Evaluated variables}

The means of variables were extracted and entered into a database. For in vitro studies (24 and $48 \mathrm{~h}$ incubations), the variables were: DM, organic matter (OM), $\mathrm{NDF}$, acid detergent fiber (ADF) digestibility, in vitro degradability and in situ disappearance of DM, NDF and ADF (DMD, NDFD, and ADFD, respectively). In vitro gas production (GP), in vivo and in situ volatile fatty acids (VFA), proportions of individual VFA, the acetate: propionate ratio (A:P), N-ammonia concentration, and ruminal $\mathrm{pH}$ (24 to $48 \mathrm{~h}$ incubations) were also extracted. For in vivo studies, the variables DM intake (DMI), average daily gain (ADG), feed conversion (FC: DMI/ ADG), and milk production and composition were also evaluated.

\section{Statistical analysis}

\section{Distribution tests}

The distribution of the data for each variable was checked using the Shapiro-Wilk, Kolmogorov Smirnov, Cramer Von Mises, and Anderson Darling tests, through the Univariate procedure of SAS statistical software (Statistical Analysis System V. 9.2, 2013). Although the present study only included normally distributed variables, the type $\mathrm{H}$ structure (or spherical) of variance-covariance was tested using the Repeated statement and Printe option of the GLM procedure. The variability of studies within the factors was tested and compared using the chi-squared test of heterogeneity using the option Proc Frec of SAS.

\section{Multiple linear and logistic models}

Logistic models were used to determine the relationship between the effects of adding EFE and other factors such as the type of study, ruminant, FP, TP, number of ingredients, AT and primary EA. Forest plot graphs were obtained using the SgPlot procedure.

\section{Analysis of variance}

Statistical analyses were performed using the Glimmix (general mixed linear models) procedure of SAS statistical software, and DM, OM, NDF, ADF, DMD, NDFD, ADFD, GP, VFA, A:P, N-ammonia, pH, DMI, ADG, FC, milk yield, milk fat and protein were evaluated considering the fixed effects described in models (1), (2) and (3), and the random effect of the repetition of an experiment (Exp) nested in the articles (Art). The estimated means and standard mean error (SEM) were reported (LsMeans/PDiff statement). Determination and variation coefficients ( $\mathrm{R}^{2}$ and $\mathrm{VC}$ ) were obtained through variance analysis using the GLM procedure. The three models were as follows:

$$
Y=\mu+[\operatorname{Exp}(A)]_{i(j)}+D i f_{k}+E f_{l}+(D i f * E f)_{k l}+\varepsilon_{i j k l}
$$


where:

$Y=$ response variable,

$\mu=$ general mean,

$[\operatorname{Exp}(A)]_{i(j)}=$ random effects of the $\mathrm{i}^{\text {th }}$ experiment within the $\mathrm{j}^{\text {th }}$ article,

$D i f_{k}=$ effect of the $\mathrm{k}^{\text {th }}$ effect reported by the author,

$E f_{l}=$ effect of the $1^{\text {th }}$ effect reported by the author,

$(\text { Dif } * E f)_{k l}=$ interaction of factors Dif $_{k}$ and $E F_{l}$,

$\varepsilon_{i j k}=$ residual effects.

$$
Y=\mu+[\operatorname{Exp}(A)]_{i(j)}+\text { Factor }_{k}+\varepsilon_{i j k}
$$

where:

$Y=$ response variable,

$\mu=$ general mean,

$[\operatorname{Exp}(A)]_{i(j)}=$ random effects of the $\mathrm{i}^{\text {th }}$ experiment within the $\mathrm{j}^{\text {th }}$ article,

Factor $_{k}=$ effect of the $\mathrm{k}^{\text {th }}$ factor (type of study, type of ruminant, type of EFE, primary EA, type of plant in diets, number of ingredients evaluated, and forage proportion),

$\varepsilon_{i j k}=$ residual effects.

$$
Y=\mu+[\operatorname{Exp}(A)]_{i(j)}+A T_{k}+T P_{l}+(A T * T P)_{k l}+\varepsilon_{i j k l m}
$$

where:

$Y=$ response variable,

$\mu=$ general mean,

$[\operatorname{Exp}(A)]_{i(j)}=$ random effects of the $\mathrm{i}^{\text {th }}$ experiment within the $\mathrm{j}^{\text {th }}$ article,

$A T_{k}=$ effect of the $\mathrm{k}^{\text {th }}$ application time of EFE,

$T P_{l}=$ effect of the $1^{\text {th }}$ primary type of plant indiets,

$(A T * T P)_{k l}=$ interaction between $\mathrm{AT}_{\mathrm{k}}$ and $\mathrm{TP}_{1}$ factors,

$\varepsilon_{i j k l m}=$ residual effects.

\section{Pearson correlation coefficients}

To assess the possible two-way linear association between pairs of normally distributed variables, Pearson correlation coefficients were computed using the CORR procedure of SAS.

\section{Results}

\section{General description of data}

The 85 sampled papers contained 407 experiments and 648 treatments ( 243 controls, and 343 treatments for in vitro, in situ, and in vivo studies, and 21 controls and 41 treatments for fiber composition studies (see Appendix A2). 


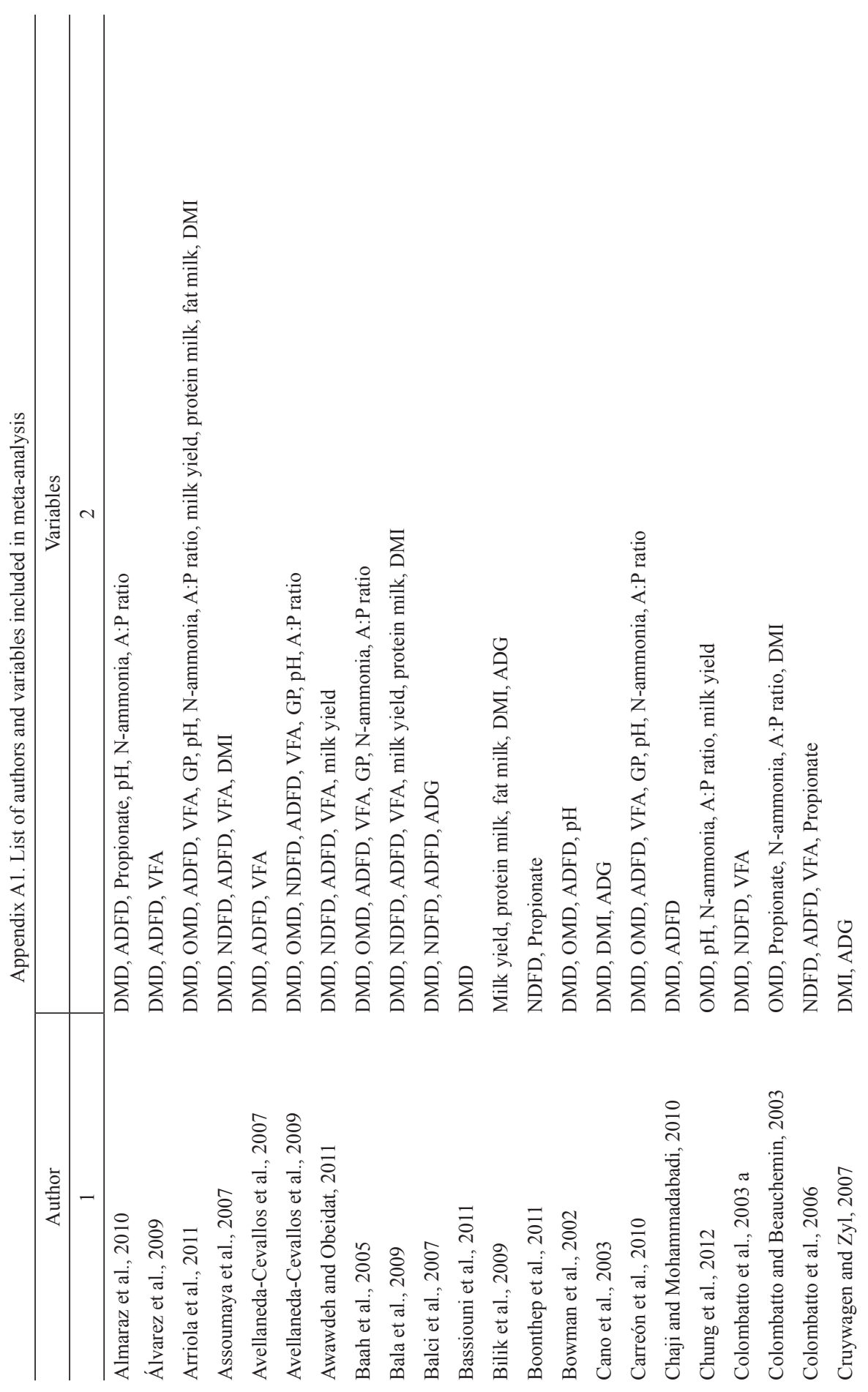




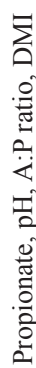

蔍

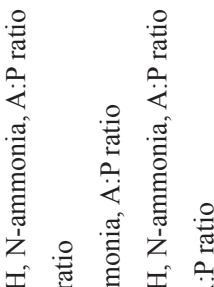

$\sum$

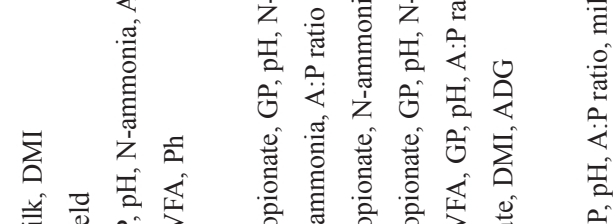

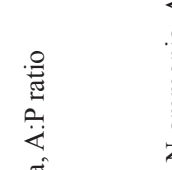

:

家

(ี

总

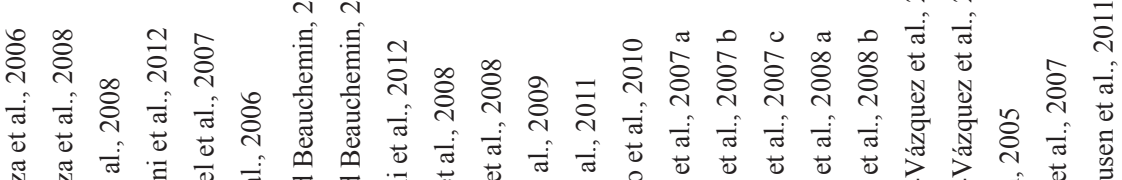

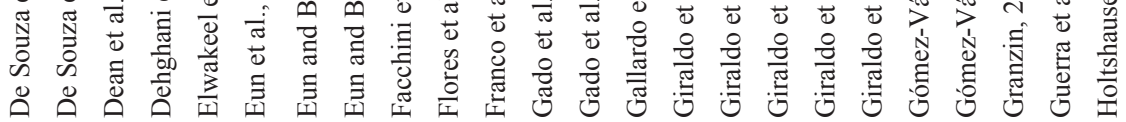




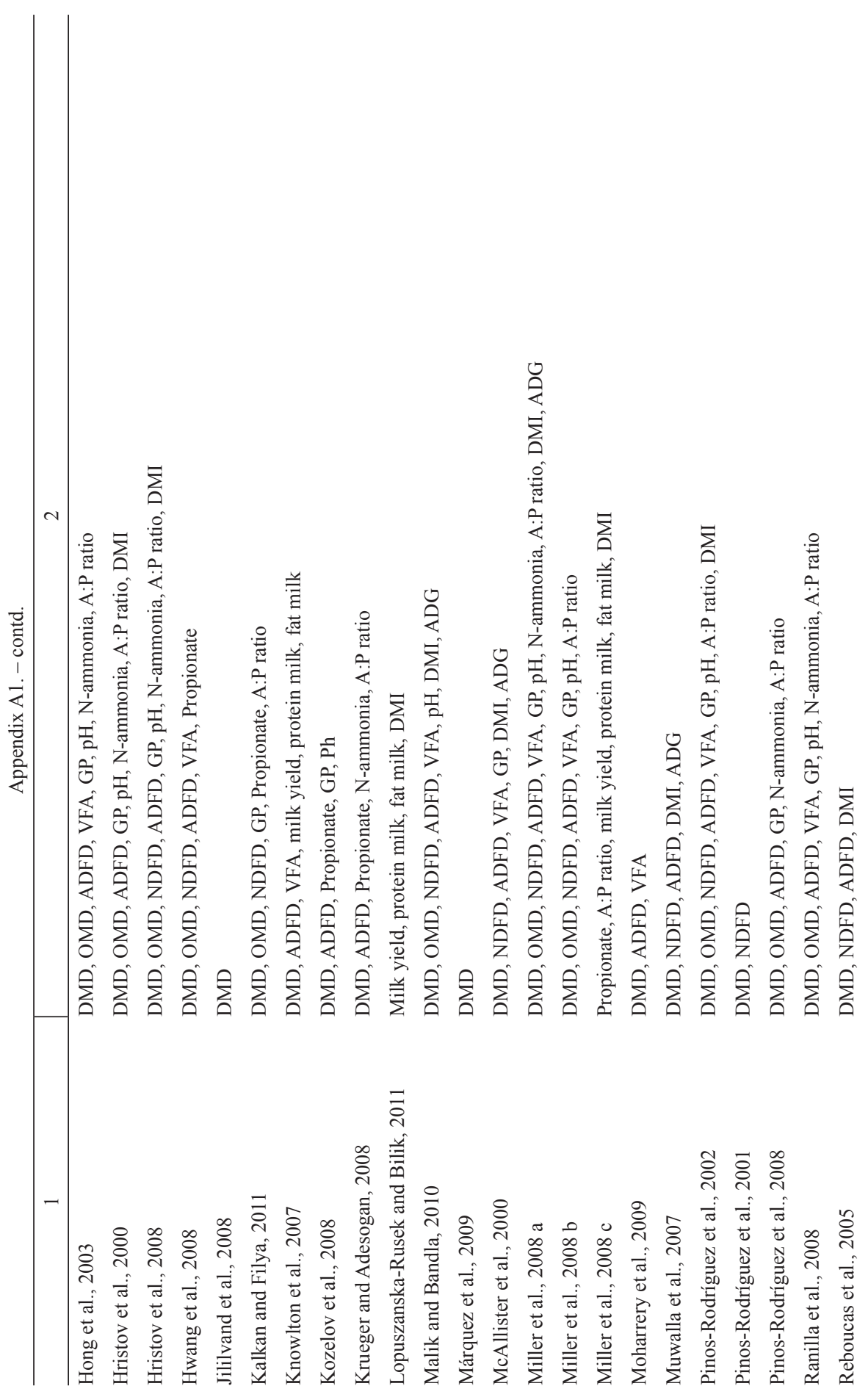




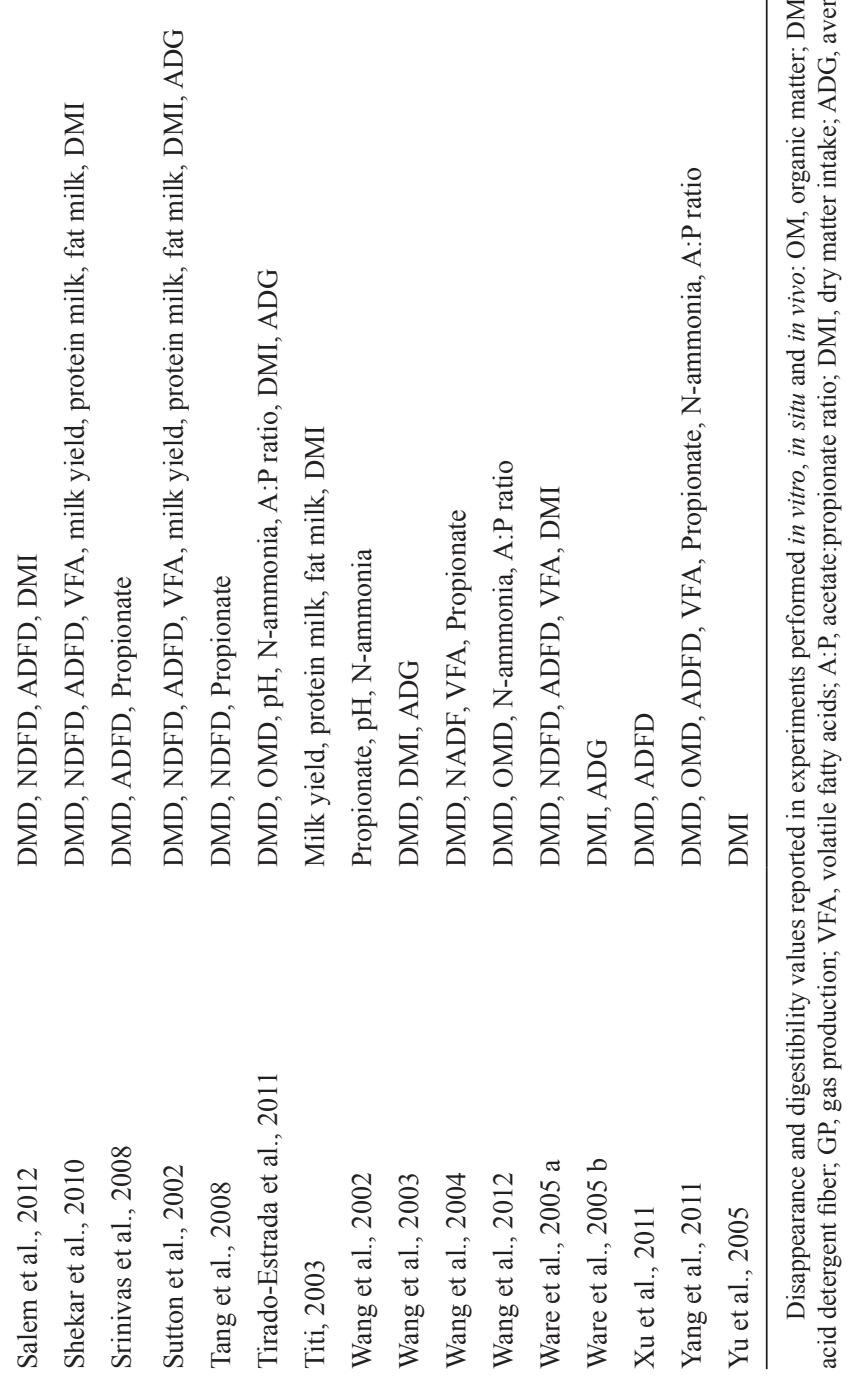




\section{Overall effects of EFE supplementation}

The average effect of including EFE on the digestibility of diet components, fermentation patterns, and milk and meat production was variable among the articles, and thus the random effect of experiments nested in the article was considered in further analysis. Table 1 presents the average change caused by EFE in ruminal fermentation patterns, degradability, disappearance, digestibility, and animal performance in in vitro, in situ or in vivo experiments (according to Model (1)). The average increase in DMD was $11 \%$ for the $52.85 \%$ of cases reported by authors as significant, and $4.88 \%$ for the $23.58 \%$ of cases reported as showing non-significant positive responses. In over $69.79 \%$ of experiments, EFE improved the NDFD and ADFD (by $11.41 \pm 4.79 \%$ and $16.55 \pm 6.35 \%$, respectively).

Over $75.83 \%$ of the data included in this analysis showed that EFE supplementation increased the in vitro GP (average, 19.84 $110.67 \%$ ) and the concentration of VFA (average, $21.85 \pm 11.43 \%$ ). In addition, $61.39 \%$ of the studies with EFE supplementation showed an increase in propionic acid concentration $(12.61 \pm 7.30 \%)$, although in $35.64 \%$ of the studies it was decreased by an average of $8.26 \pm 6.23 \%$.

In $53.75 \%$ of the studies in which EFE supplementation had a significant effect $(\mathrm{P}<0.05)$ the A:P ratio decreased by $8.89 \pm 0.10 \%$. Furthermore, $55.06 \%$ of studies with EFE supplementation demonstrated an increase in $\mathrm{N}$-ammonia concentration (average, $13.16 \pm 0.50 \%$ ), while $40.45 \%$ of the studies showed a decrease (average, $-7.78 \pm 4.70 \%$ ). The $\mathrm{pH}$ increased in $30 \%$ of the studies (average $1.68 \pm 0.25 \%$ ) but decreased in $53.33 \%$ of cases (average, $-2.1 \pm 0.3 \%$ ).

Milk production improved by $9.28 \pm 3.03 \%$ with EFE use (in $81.82 \%$ of experiments), and fat and crude protein contents also increased by $6.03 \pm 13.68 \%$ and $4.30 \pm 2.45 \%$ (in over $54.55 \%$ of experiments), respectively. The ADG was positively affected by EFE supplementation (average, $17.57 \pm 6.98 \%$ ) in $67.86 \%$ of the studies.

\section{Effects of EFE supplementation associated with other factors}

The effect of using EFE was associated with other factors using logistic models (Table 2). The type of EA (proportion of Cel and Xyl) affected the response of OMD, VFA and milk yield $(\mathrm{P}<0.02)$, and tended to affect the OMD, milk protein and fat content and ADG $(\mathrm{P}<0.08)$. The TP and types of ruminant affected the responses of GP and VFA $(\mathrm{P}<0.01)$ to the use of EFE, whereas the FP affected the GP, VFA and $\mathrm{ADG}(\mathrm{P}<0.04)$, and the AT of diets altered the effect of EFE on GP, ruminal $\mathrm{pH}$ and $\mathrm{N}$ ammonia, milk yield and milk protein $(\mathrm{P}<0.02)$. Although, the effects of EFE on DMD, GP, VFA, A:P ratio, and propionate were similar among in vitro, in situ and in vivo studies $(\mathrm{P}>0.12), \mathrm{OMD}$ and NDFD responses varied among type of studies $(\mathrm{P}<0.01)$.

The forest plot graphs represent the changes caused by EFE addition within the confidence interval (95\%); averages near to the vertical line represent no significant effect (Figure 1). Although the results were highly variable, EFE had positive effects on digestibility, GP and VFA but was primarily associated with factors such as the type of ruminant, TP, FP and EA. Depending on the FP, using EFE could improve the ADG, but some types of EA can enhance milk composition and production. The variability of the data and the adverse effects on GP, N-ammonia, and milk yield were associated with the AT of EFE. 


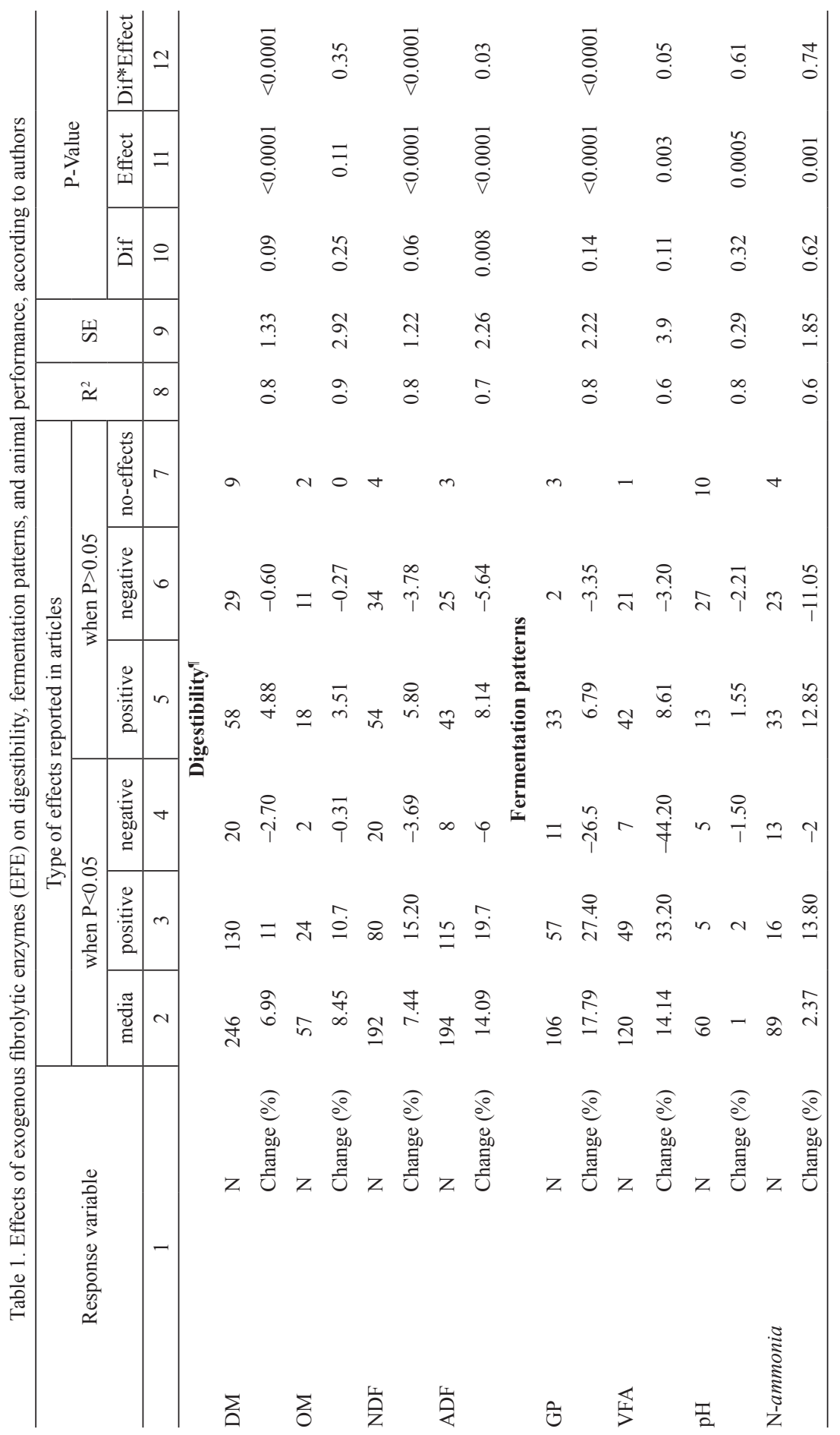




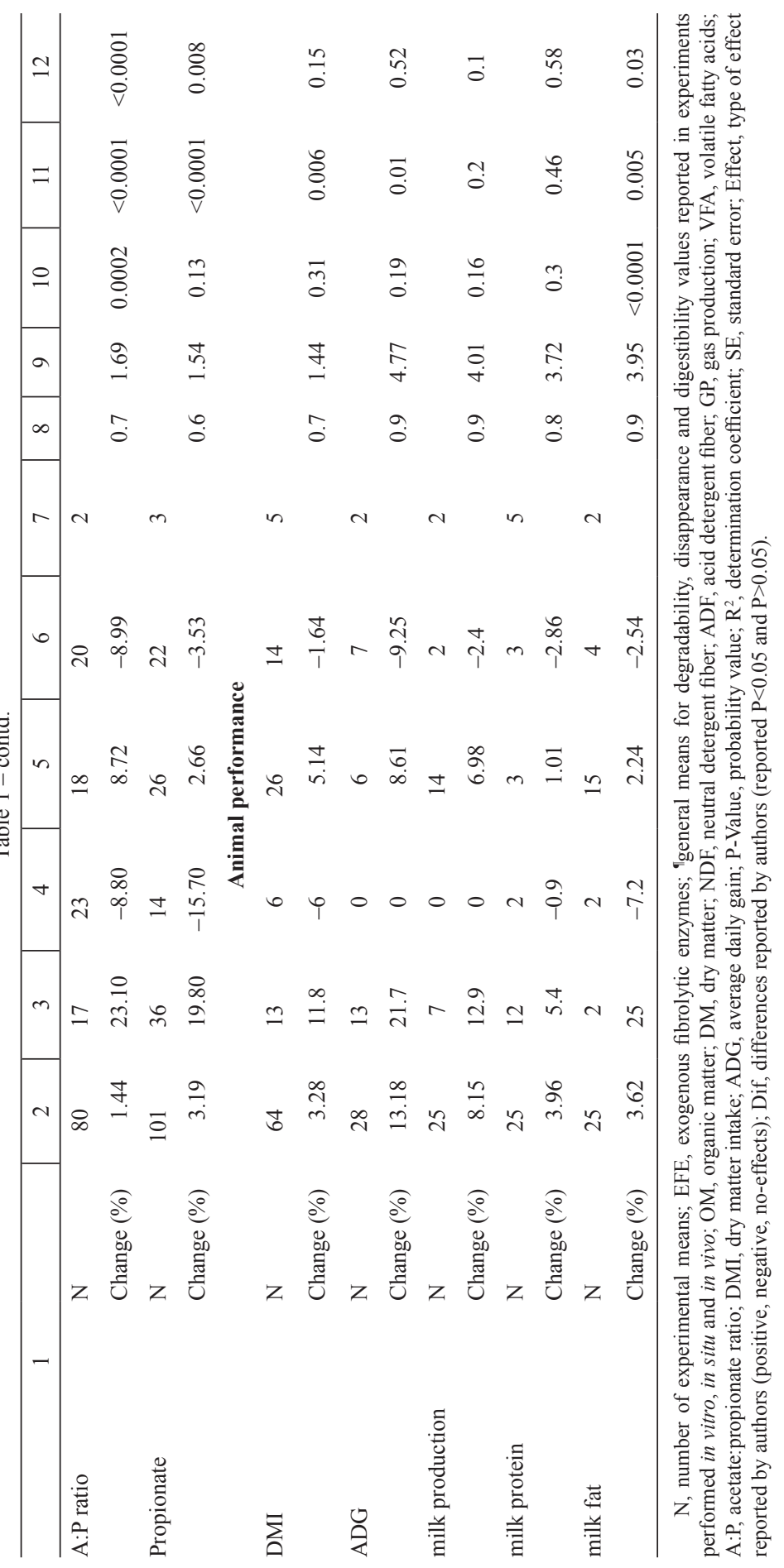




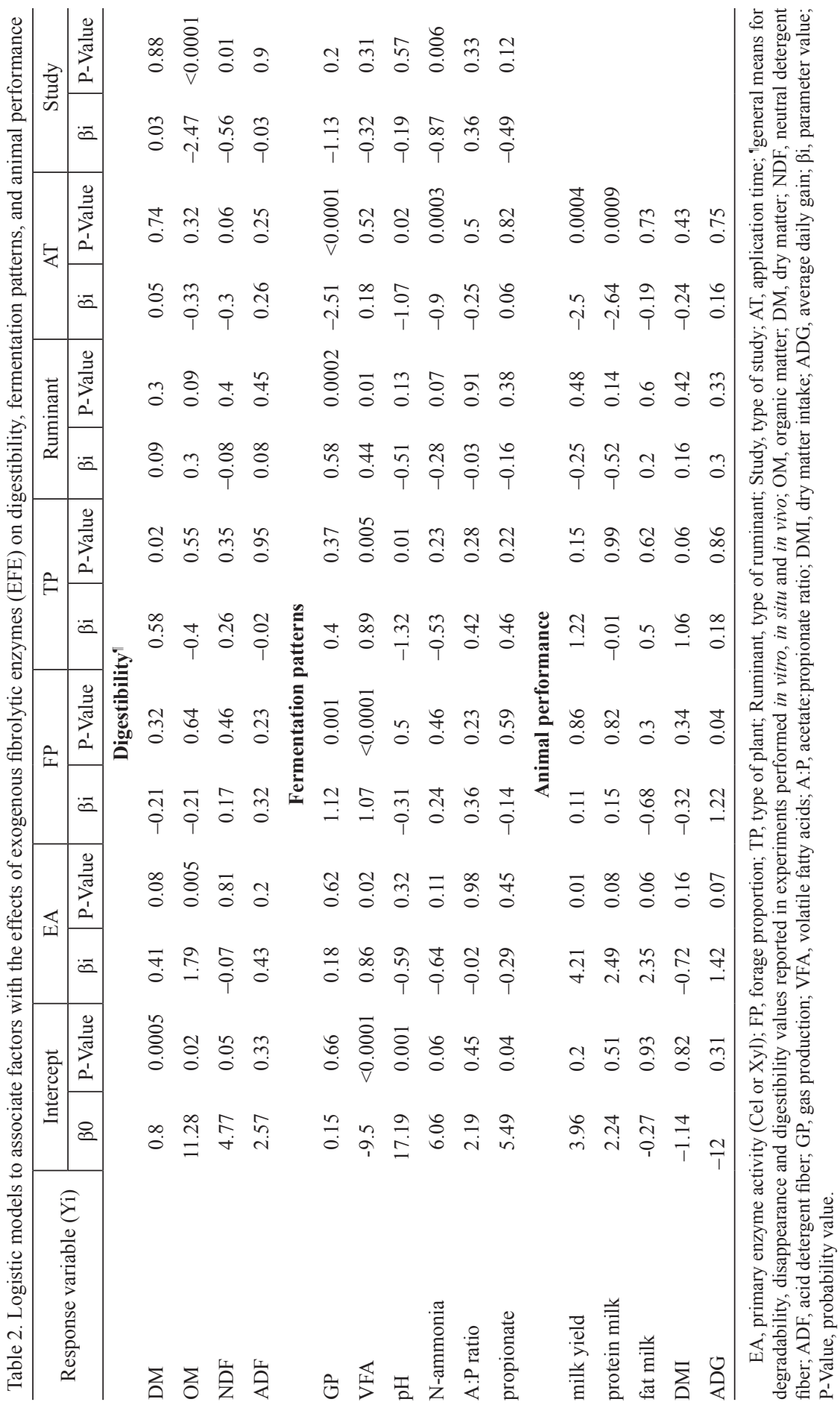




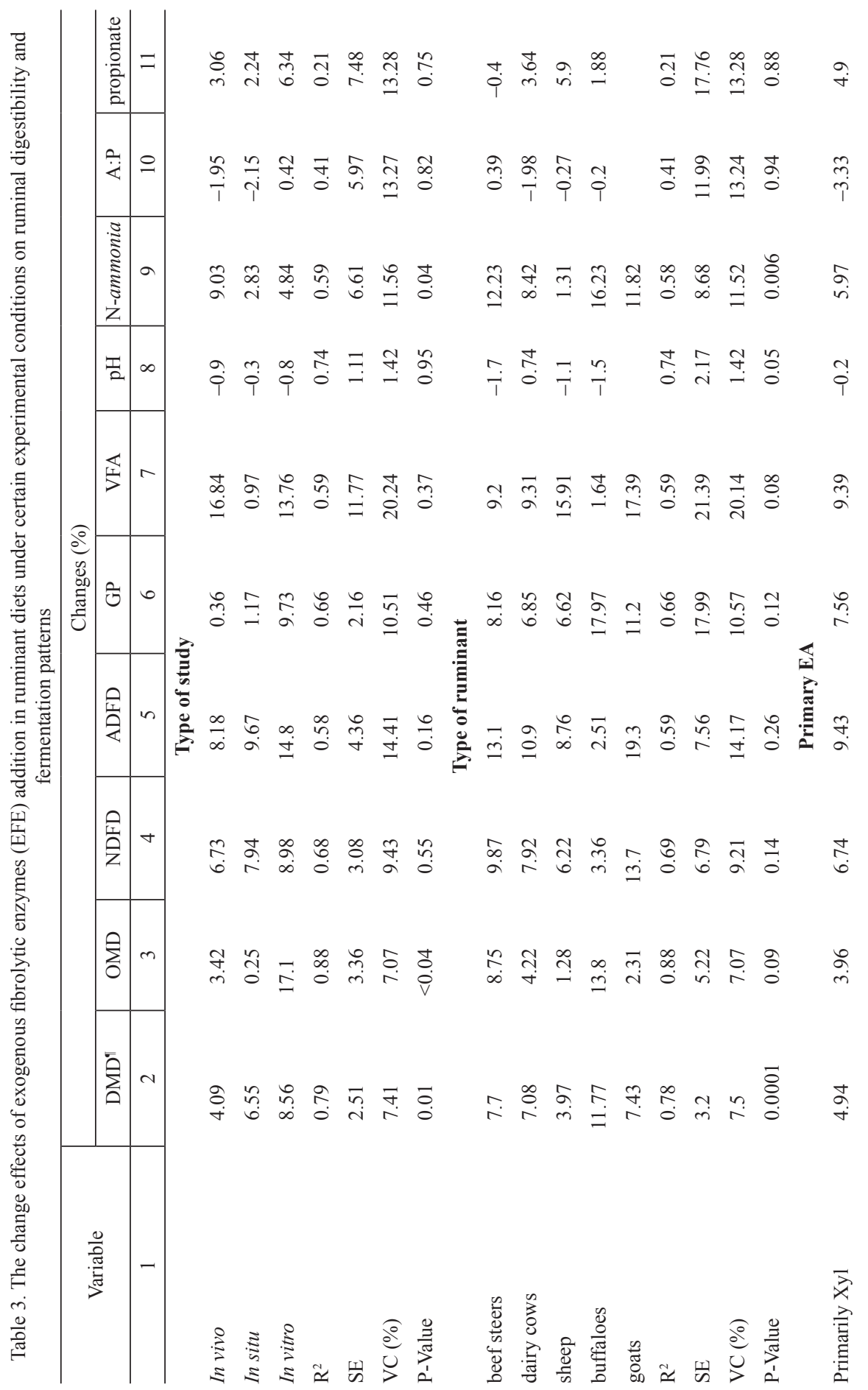




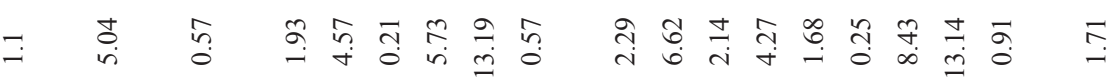

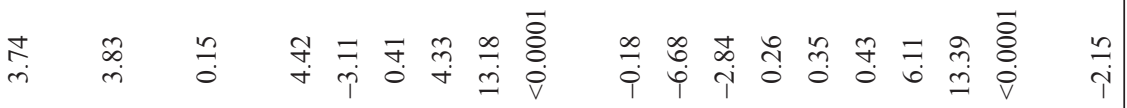

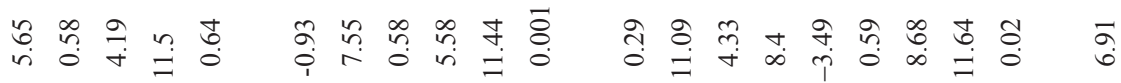

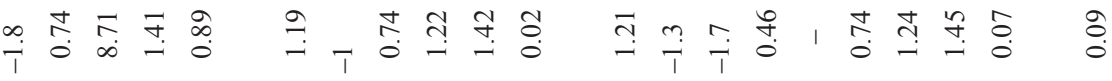

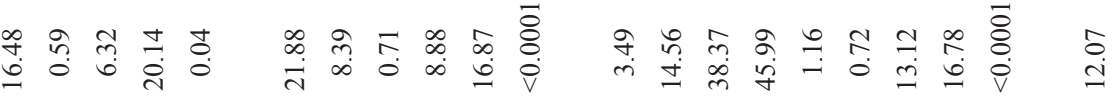

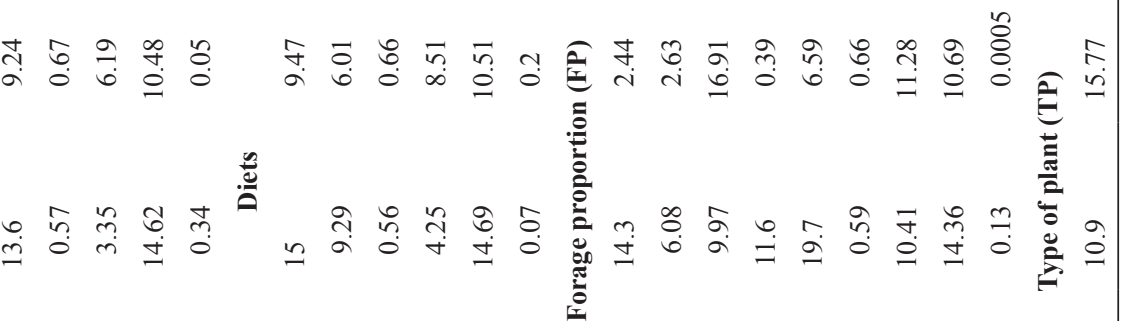

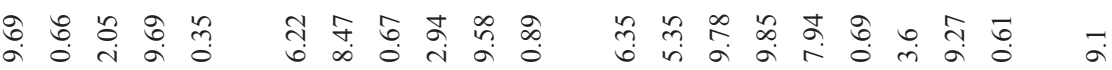

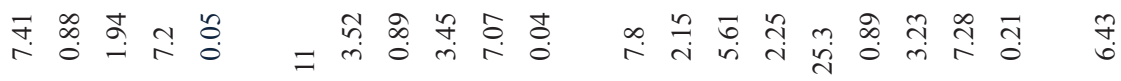

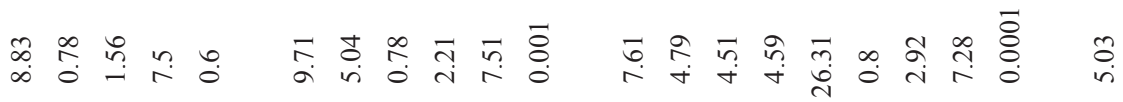

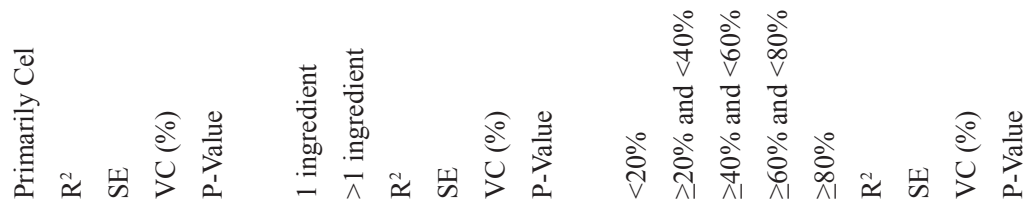




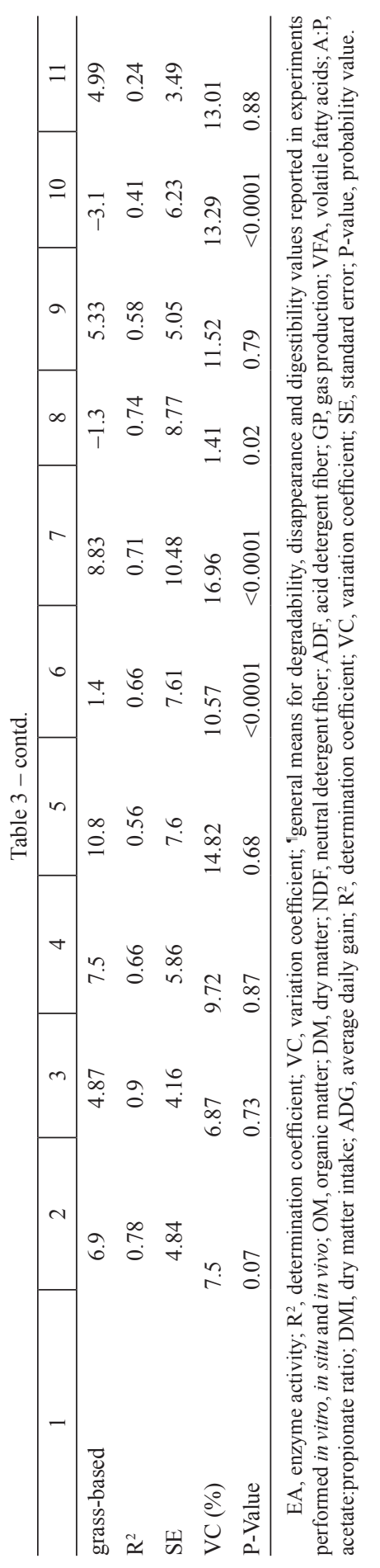




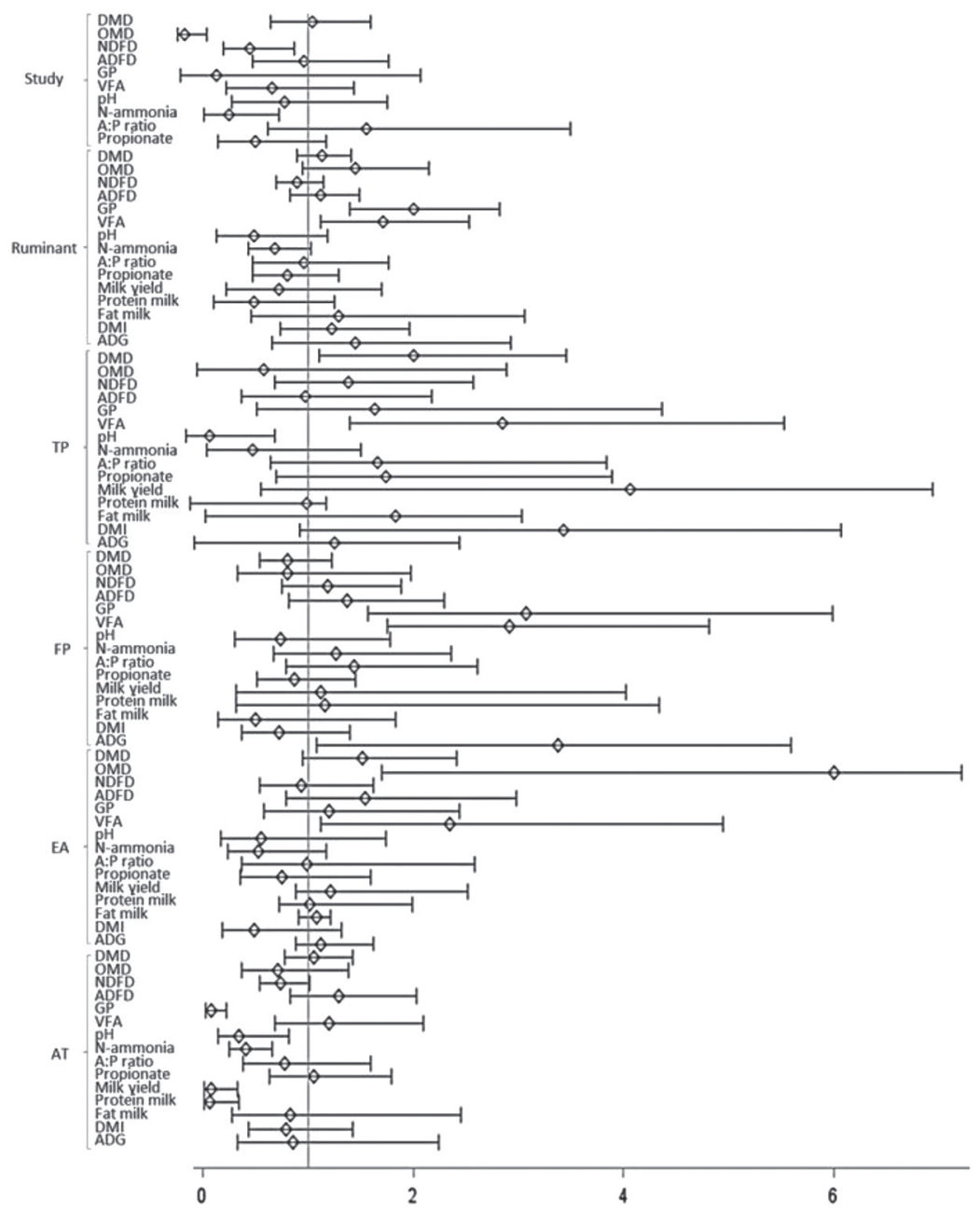

Figure 1. Forest plot graph, average effects of EFE applied under different conditions: Types of ruminant, studies (in vitro, in situ and in vivo), plants (TP: legume and grass-based diets), primary enzyme activity (EA: cellulases and xylanases), and application times (AT) on digestibility, fermentation patterns, and productive animal performance

The average changes for other factors on diet digestibility and productive animal performance are presented in Tables 3 and 4 (according to Model (2)). In vitro studies overestimated the effects of EFE on DM and OM degradability $(\mathrm{P}<0.04)$, primarily in experiments that evaluated one ingredient $(\mathrm{P}<0.04)$. The highest effects of EFE addition on DMD were observed in diets containing $\mathrm{FP} \geq 80 \%(\mathrm{P}<0.001)$, but EFE had better effect on VFA and the A:P ratio in diets with $\mathrm{FP} \geq 40 \%$ but $<80 \%$ $(\mathrm{P}<0.0005)$. Although $\mathrm{EFE}$ in $\mathrm{FP}<40 \%$ had the best effect on increasing the DMI, EFE had better effect on ADG as the FP increased over $40 \%(\mathrm{P}<0.03)$. 
Table 4. The change effects of exogenous fibrolytic enzymes (EFE) addition in ruminant diets under certain experimental conditions on productive animal performance

\begin{tabular}{|c|c|c|c|c|c|}
\hline \multirow{2}{*}{ Item } & \multicolumn{5}{|c|}{ Changes (\%) } \\
\hline & milk yield & protein milk & fat milk & ADG & DMI \\
\hline \multicolumn{6}{|c|}{ Type of ruminant } \\
\hline beef steers & & & & 19.8 & 1.08 \\
\hline dairy cows & 8.54 & 4.68 & 1.86 & & \\
\hline sheep & & & & 14.3 & 5.53 \\
\hline goats & 12.99 & 0 & 1.3 & 15.6 & 7.83 \\
\hline $\mathrm{R}^{2}$ & 0.96 & 0.72 & 0.35 & 0.63 & 0.89 \\
\hline SE & 16.94 & 13.19 & 20.79 & 7.4 & 16.13 \\
\hline VC (\%) & 3.87 & 8.69 & 18.7 & 8.31 & 10.05 \\
\hline P-Value & 0.9 & 0.66 & 0.99 & 0.42 & 0.15 \\
\hline \multicolumn{6}{|c|}{ Primary EA } \\
\hline primarily xyl & 4.5 & 1.14 & -0.3 & 12.7 & 2.41 \\
\hline primarily cel & 25.9 & 12.35 & 12.14 & 14.3 & 0.92 \\
\hline $\mathrm{R}^{2}$ & 0.97 & 0.72 & 0.35 & 0.63 & 0.89 \\
\hline SE & 7.6 & 4.61 & 6.95 & 1.77 & 6.47 \\
\hline VC $(\%)$ & 3.88 & 8.67 & 18.7 & 8.45 & 10.4 \\
\hline P-Value & 0.006 & 0.002 & $<0.001$ & 0.07 & 0.73 \\
\hline \multicolumn{6}{|c|}{ Forage proportion (FP) } \\
\hline$<40 \%$ & 2.78 & 0.91 & 2.08 & 1.4 & 7.57 \\
\hline$\geq 40 \%$ and $<60 \%$ & 8.44 & 2.08 & 0.12 & 17.77 & 1.79 \\
\hline$\geq 60 \%$ & 9.61 & 7.63 & 4.18 & 25.84 & 2.76 \\
\hline $\mathrm{R}^{2}$ & 0.97 & 0.73 & 0.37 & 0.63 & 0.92 \\
\hline SE & 10.19 & 6.79 & 8.04 & 22.38 & 10.16 \\
\hline VC (\%) & 3.96 & 9.26 & 19.8 & 8.57 & 9.36 \\
\hline P-Value & 0.37 & 0.19 & 0.74 & 0.03 & 0.008 \\
\hline \multicolumn{6}{|c|}{ Type of plant (TP) } \\
\hline Legume-based & 1.05 & 1.39 & 0.34 & 19.7 & -4 \\
\hline Grass-based & 10.88 & 4.96 & 2.71 & 12.3 & 2.84 \\
\hline $\mathrm{R}^{2}$ & 0.96 & 0.72 & 0.35 & 0.66 & 0.89 \\
\hline SE & 15.75 & 10.42 & 13.1 & 4.08 & 13.03 \\
\hline VC (\%) & 3.88 & 8.69 & 18.7 & 8.24 & 10.33 \\
\hline P-Value & 0.29 & 0.54 & 0.71 & 0.37 & 0.02 \\
\hline
\end{tabular}

EA, enzyme activity; ADG, average daily gain, DMI, dry matter intake; $\mathrm{R}^{2}$, determination coefficient; $\mathrm{VC}$, variation coefficient; SE, standard error; P-value, probability value.

Adding EFE to legume-based diets led to significant increases in GP and VFA and in grass-based diets had the best effect on the A:P ratio and DMI $(\mathrm{P}<0.02)$. Supplementing primarily Cel promoted the best improvements in OMD, GP and VFA $(\mathrm{P}<0.05)$, and in milk yield and milk protein and fat content $(\mathrm{P}<0.006)$. 


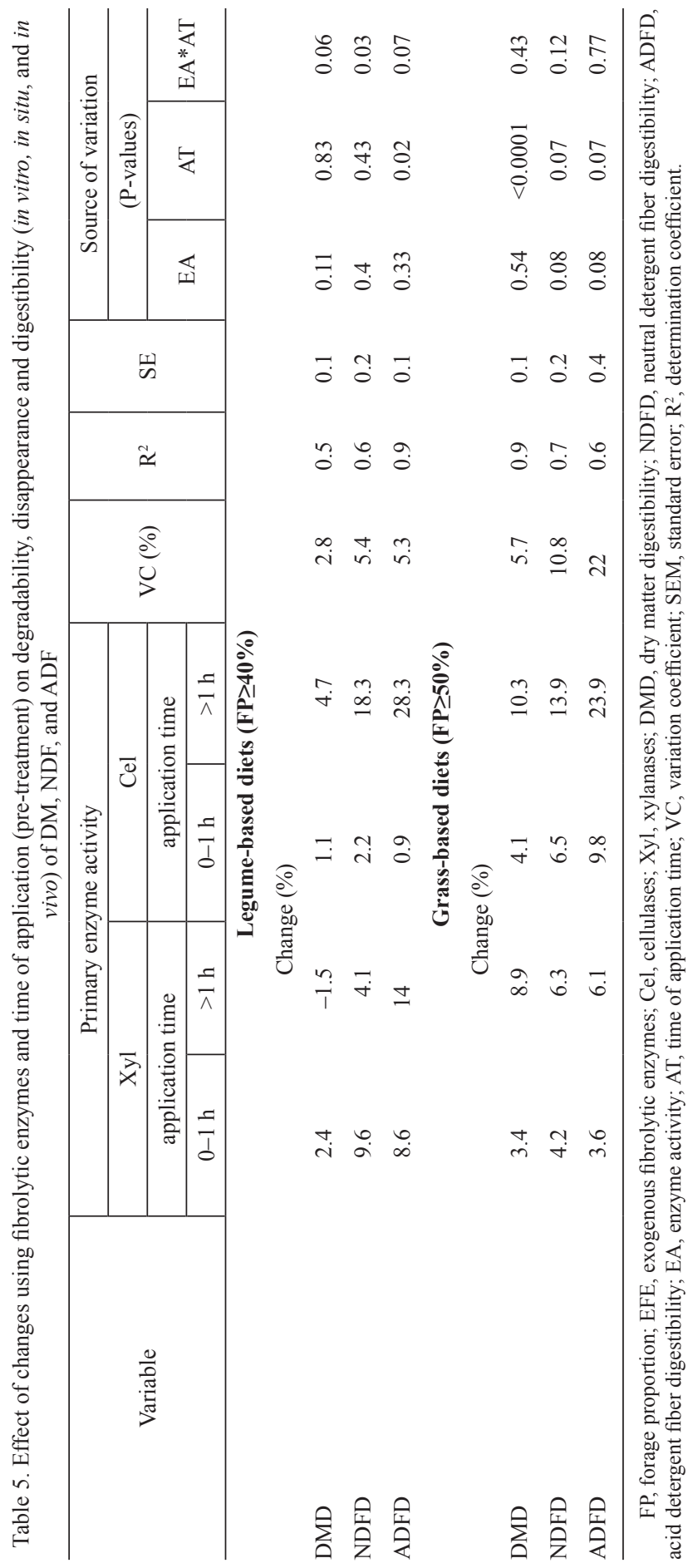


The effects of the time of application of EFE products to the diets before feeding ruminants are presented in Table 5 (according to Model (3)). There was an interaction between the time of application of EFE and the primary type of EA supplemented to legume-based diets on NDFD $(\mathrm{P}<0.05)$. At least $1 \mathrm{~h}$ of pre-treatment with both $\mathrm{Cel}$ and $\mathrm{Xyl}$ improved the ADFD of legume-based diets $(\mathrm{FP} \geq 40 \% ; \mathrm{P}<0.02)$, and the DMD of grass-based diets $(\mathrm{FP} \geq 50 \% ; \mathrm{P}<0.0001)$ but applying $\mathrm{EFE}$ at least $1 \mathrm{~h}$ prior to feeding enhanced the NDFD and ADFD of grass-based diets ( $\mathrm{FP} \geq 50 \%$; $\mathrm{P}<0.07)$.

\section{Correlations}

Pearson correlations (Table 6) were different from zero (positively correlated) between paired DMD, NDFD, and ADFD ( $r>0.59, \mathrm{P}<0.0001)$, DMD significantly correlated with GP and VFA ( $r>0.36$; $<<0.01)$, NDFD, ADFD, and DMD were positively correlated with milk yield $(\mathrm{r}>0.64 ; \mathrm{P}<0.05)$. In addition, DMD tended to be correlated with $\mathrm{CP}$ milk $(\mathrm{r}=0.59 ; \mathrm{P}<0.1)$. $\mathrm{DMD}$ and ADFD were positively correlated with ADG $(r>0.59 ; \mathrm{P}<0.05)$.

Table 6. Pearson correlations between digestibility, fermentation patterns, and animal performance variables

\begin{tabular}{|c|c|c|c|c|c|c|c|c|c|c|c|}
\hline & DMD & NDFD & ADFD & GP & VFA & $\mathrm{A}: \mathrm{P}$ & Propionate & $\begin{array}{c}\mathrm{CP} \\
\text { milk }\end{array}$ & $\begin{array}{c}\text { Fat } \\
\text { milk }\end{array}$ & $\begin{array}{l}\text { Milk } \\
\text { yield }\end{array}$ & DMI \\
\hline NDFD & $0.65^{* * *}$ & & & & & & & & & & \\
\hline ADFD & $0.59^{* * * *}$ & $0.71^{* * * *}$ & & & & & & & & & \\
\hline GP & $0.36 * *$ & 0.06 & -0.12 & & & & & & & & \\
\hline VFA & $0.36 * *$ & 0.08 & 0.13 & 0.51 & & & & & & & \\
\hline $\mathrm{A}: \mathrm{P}$ ratio & -0.02 & -0.05 & 0.07 & $0.40^{* *}$ & * 0.51 ** & & & & & & \\
\hline Propionate & -0.01 & 0.19 & 0.16 & $0.34^{*}$ & 0.06 & -0.09 & & & & & \\
\hline CP milk & $0.59^{\S}$ & -0.3 & -0.26 & -0.51 & -0.1 & 0.23 & -0.05 & & & & \\
\hline Fat milk & 0.21 & 0.31 & 0.35 & 0.02 & $-0.98^{\S}$ & $0.98^{\S}$ & 0.03 & $0.72^{* * * *}$ & & & \\
\hline Milk yield & $0.76^{*}$ & $0.79^{* * * *}$ & $0.64^{* * *}$ & $-0.75^{\S}$ & $0.91^{\S}$ & $0.98^{\S}$ & -0.21 & $0.77^{* * *}$ & $0.46^{*}$ & & \\
\hline DMI & -0.16 & -0.28 & -0.22 & 0.25 & 0.19 & 0.38 & 0.02 & 0.19 & 0.08 & 0.2 & \\
\hline $\mathrm{ADG}$ & $0.72 * * *$ & $=0.43$ & $0.59^{*}$ & . & . & . & $0.98^{*}$ & 0.31 & $-0.69^{*}$ & -0.1 & $0.60^{\S}$ \\
\hline
\end{tabular}

Disappearance and digestibility values reported in experiments performed in vitro, in situ and in vivo: OM, organic matter; DM, dry matter; NDF, neutral detergent fiber; ADF, acid detergent fiber; GP, gas production; VFA, volatile fatty acids; A:P, acetate:propionate ratio; DMI, dry matter intake; ADG, average daily gain. Significant ${ }^{\circledR} \mathrm{P}<0.10 ;{ }^{*} \mathrm{P}<0.05 ; * * \mathrm{P}<0.01 ; * * * \mathrm{P}<0.0001$.

GP tended to be negatively correlated with milk yield and the A:P ratio with milk fat $(\mathrm{r}=-0.75$ and -0.98 , respectively; $\mathrm{P}<0.1)$, but the milk yield tended to be positively correlated with VFA and the A:P ratio. $(r>0.91 ; \mathrm{P}<0.1)$. ADG was positively correlated with propionate $(\mathrm{r}=0.98 ; \mathrm{P}<0.05)$. $\mathrm{CP}$ milk, milk fat and milk yield positively correlated $(\mathrm{r}>0.46 ; \mathrm{P}<0.05)$, and ADG tended to be correlated with DMI $(\mathrm{r}=0.6$; $\mathrm{P}<0.1)$. 


\section{Discussion}

Most of the data in this review came from in vitro studies, mainly using sheep, and dairy and beef cattle, and with similar amounts of information on the primary activity of xylanase and cellulose enzymes. Most of the included studies used diets based on grass $(73.30 \%)$ and a forage proportion $\geq 60 \%(63.89 \%)$. The time of enzyme application was mainly between 0 and $24 \mathrm{~h}$ prior to the in vitro, in situ or in vivo evaluations (see Appendix A2).

Chung et al. (2012) and Wang et al. (2012) associated the direct hydrolysis of xylose and cellulose by EFE with changes in the structure of the cell wall and the successive populations of microorganisms, ruminal microorganisms working synergistically with endogenous enzymes toward promoting the fiber digestibility of diets, and positively affecting the ruminal fermentation patterns (Yang et al., 2011; Salem et al., 2015 b). Increasing the breaking of linkages and the release of sugars in the rumen could reduce $\mathrm{CH}_{4}$ emissions (Beauchemin et al., 2008; Knapp et al., 2014; Elghandour et al., 2016) and improve characteristics of animal production such as DMI, ADG and FC (Valdés et al., 2015).

Consistent with recent studies where Xyl and Cel improved the degradability of OM, DM, CP, NDF, and ADF, and the proportion of VFA (López-Aguirre et al., 2016 a; Vallejo et al., 2016 a; Vallejo-Hernández et al., 2018), the present analysis shows how in the majority of experiments, the use of EFE had positive effects on the digestibility of the diet components (DM, NDF, and ADF), the GP, VFA and A:P ratio, and the productive characteristics of the animals. However, the forest plot showed the high variability of EFE effects among treatments and studies, with effects primarily depending on the type of ruminant, plant, EA and FP.

Primarily cellulase enzyme products led to better responses in DM, NDF, ADF, fermentation patterns, milk protein and fat and milk yield than primarily xylanase products. This difference is significant $(\mathrm{P}<0.05)$ for VFA, production and quality of milk. The mechanism of hemicellulose removal (primarily composed of xylose, 48 to $66 \%$, and arabinose, 10.4 to $35 \%$ ) involves the breaking of some hemicellulose-cellulose bonds to increase the accessibility to cellulose (Eun and Beauchemin, 2007 a, b). Thus, any deficiency of cellulase enzyme activity and/or excess xylanase activity could adversely affect the ruminal population of microorganisms (Eun and Beauchemin, 2008; Eun et al., 2007 a). For example, Eun et al. (2007 b) observed a linear trend between increasing endoglucanase EA and the improvement of alfalfa hay and corn silage DM degradability. Also, Yu et al. (2005) reported multiple linear models for the effect of 23 enzyme products in vitro in ruminal fluid on the DM digestibility of oat hulls; one model indicated that $55 \%$ of the DM digestibility was attributed to cellulases and $\beta$-glucosidases, while the same model showed $r^{2}=0.74$ when including xylanase, endoglucanase I, endoglucanase II, ferulic acid esterase, $\beta$-glucosidase and cellulase enzyme activities.

López-Aguirre et al. (2016 b) and Vallejo et al. (2016 b) found that although in most experiments with both $\mathrm{Cel}$ and $\mathrm{Xyl}$ the ruminal degradability of fiber, DM and OM, GP and fermentation patterns improved, primarily Cel products gave the best results. Morsy et al. (2016) tested Cel and Xyl products in 21 buffaloes fed with rice 
straw as forage $(\mathrm{FP}=60 \%)$ and reported that the effects of supplementing primarily Cel on milk, fat, and conjugated linoleic acid yields were higher than when supplementing with Xyl. In beef steers, Salem et al. (2013) tested a primarily Cel enzymatic product, and although the EFE did not affect the DMI, Cel improved the digestibility of DM, OM, CP, NDF and ADF, the fermentation patterns, and the FC.

Differences in ruminal microbiota had been reported across the different species of ruminants according to the species, breed, and the physiological stages (Li et al., 2019, 2009; Jami and Mizrahi, 2012; Lee et al., 2012) and feeding strategies (Petri et al., 2012; Morgavi et al., 2013), affecting the potential DMD, NDFD (Petri et al., 2012; Shabar et al., 2016), related to the kinetics of GP and fermentation patterns (Miranda-Romero et al., 2020), additional studies had related changes in rumen microbial phylotypes and feed efficiency (Zhou et al., 2009; Jewell et al., 2015; Li et al., 2019).

In addition to the type of ruminant, the effects of the type of EA might depend on the type and proportion of forage included in the diet. Colombatto et al. (2003 a) conducted a multiple linear regression to determine the effect on NDF degradability of 22 enzyme products tested in ruminal fluid; at $18 \mathrm{~h}$ the xylanase EA was positively correlated with the improvement of alfalfa hay NDF degradability, but negatively correlated with the improvement of corn silage NDF degradability. In addition, Eun and Beauchemin (2007 a, b) assayed in vitro (in ruminal fluid) extracts of enzymes from Trichoderma longibrachiatum, reporting that the proportion of cellulases showed a coefficient of regression of 0.26 with the improvement of NDF digestibility of alfalfa, but of 0.72 with the improvement of corn silage NDF digestibility.

Pretreatment at least one hour before feeding enables the partial hydrolysis of fiber, increasing the availability of initial non-structural carbohydrates, which can change the patterns of colonization of ruminal microorganisms (Yu et al., 2005; Wang et al., 2012; Díaz et al., 2015). During the ensiling process, the addition of EFE can reduce the proportions of ADF, NDF, cellulose and hemicellulose (Alsersy et al., 2015; Gado et al., 2017; Kholif et al., 2017).

Previous studies associated improvement in NDF digestibility with better animal performance. Oba and Allen (1999, 2000 a, b, 2005) published regression models, associating each unit improvement in NDF degradability with the increase in DMI $(0.168 \mathrm{~g} / \mathrm{d})$ and fat-corrected milk production $(0.249 \mathrm{~kg} / \mathrm{d})$. The analysis in the present study found that EFE positively affected the NDFD, which is correlated with greater milk yield $(r=0.79)$ and not the ADG $(r=0.01)$ Salem et al. (2013) also reported positive EFE effects on the degradability of fiber and dietary components, fermentation patterns, and the live-weight gain and FC of beef steers.

\section{Limitations}

Some effects related to the use of enzymes in ruminants are inconsistent due mainly to enzymatic products handling, the dose, diet ingredients, time and application methods (Beauchemin et al., 2003). In many cases, the products evaluated for ruminants feed application do not contain the appropriate mixture of types of enzymes decreasing their effect on fiber digestibility (Yu et al., 2005; Eun and Beauchemin, 2007 a, 2008). 


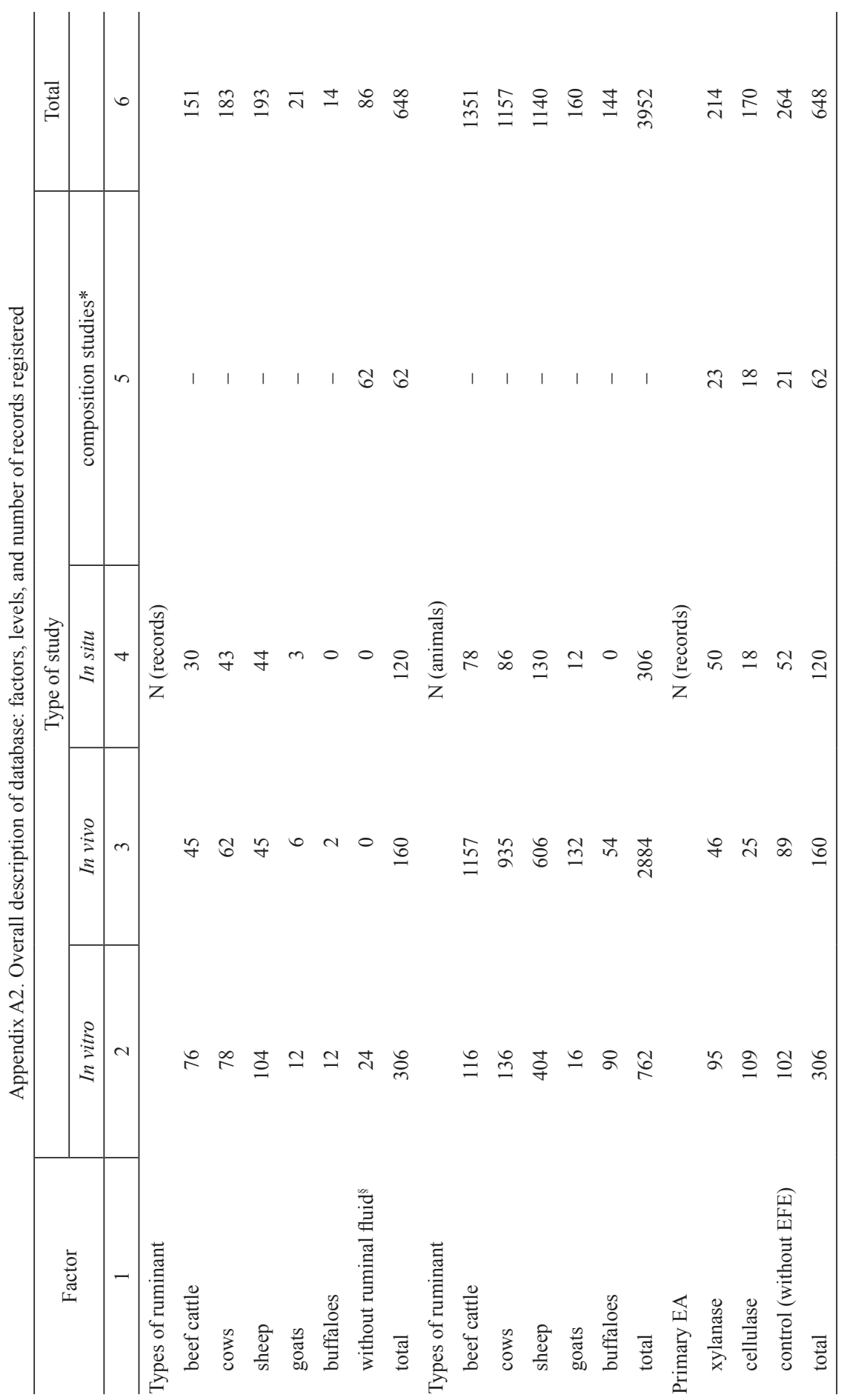




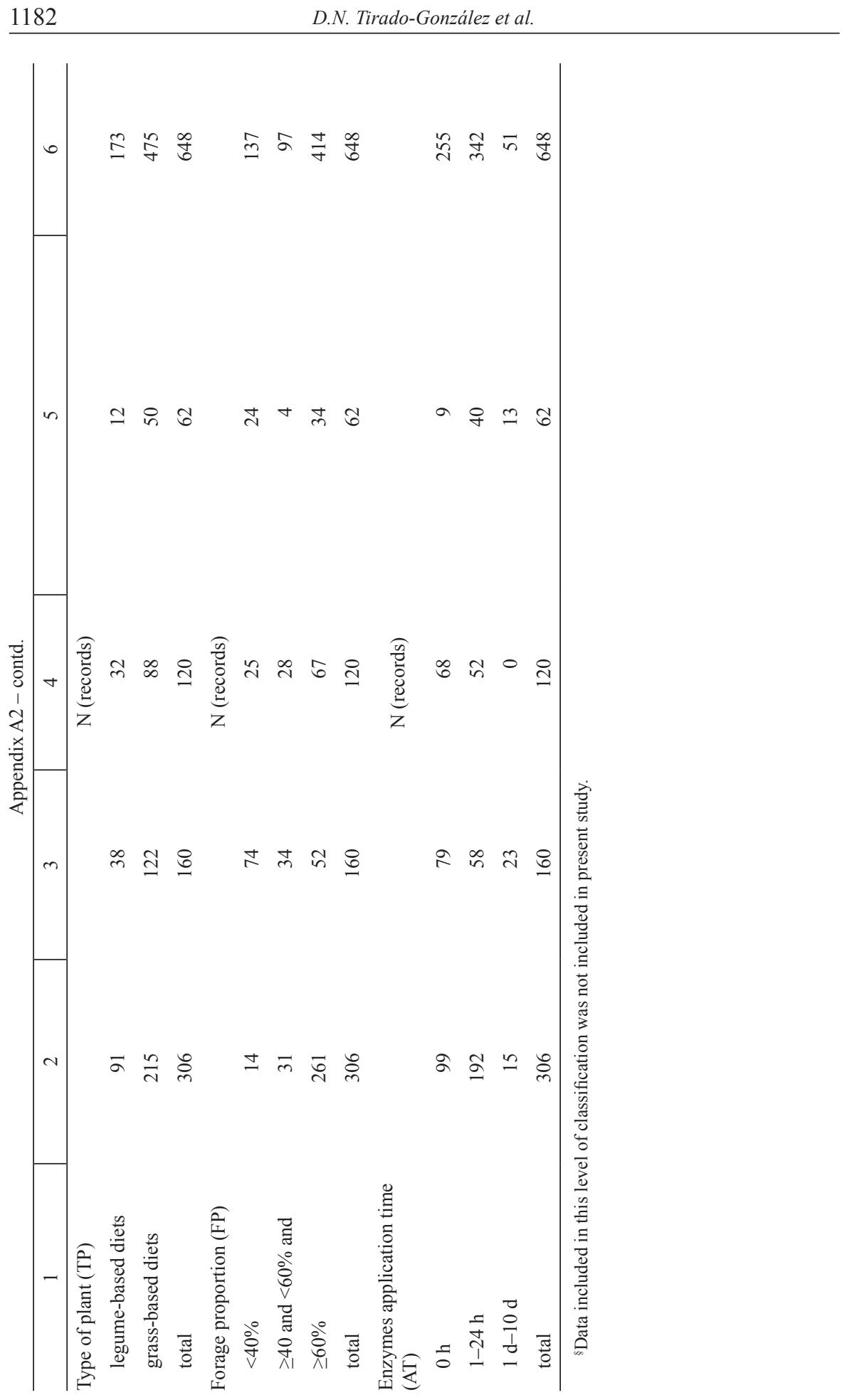




\section{Supplementary Information}

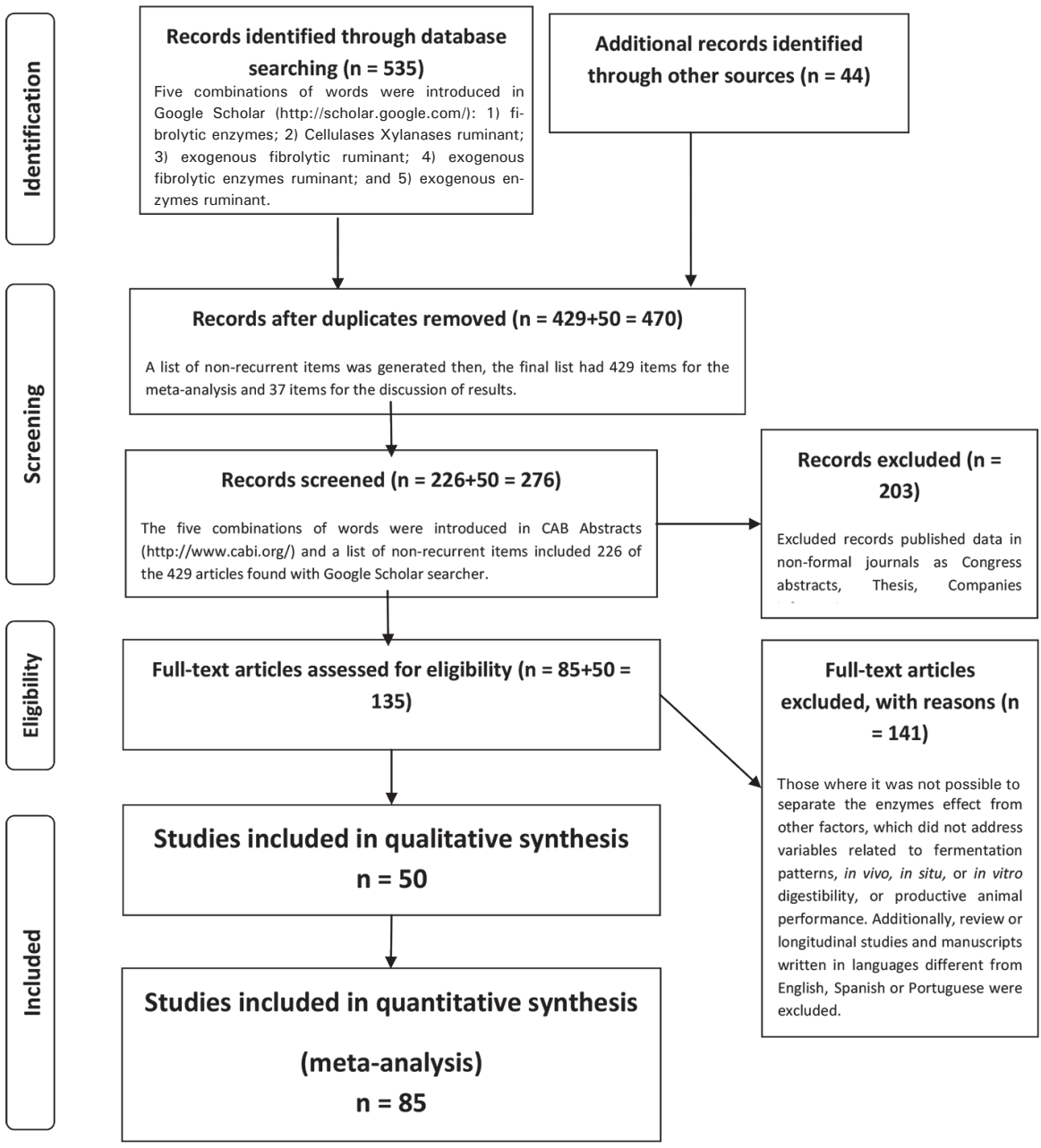

Figure Suppl. 1. Preferred Reporting Items for Systematic reviews and Meta-Analyses (PRISMA) flow diagram (Moher et al., 2009)

In order to find products which contain specific forms of enzymes for improving the fiber degradation and combine appropriate proportions of different enzymatic activities to increase the results consistency an adequate biochemical characterization of the products is also required, considering that the optimal conditions for the 
enzyme activities could be different than those under enzymes are expected to act, for ruminant feed applications, the $\mathrm{pH}$ and temperature used in the assays should be at $39^{\circ} \mathrm{C}$ and $\mathrm{pH}$ between 5.8 and 6.8 , similar to the ruminal conditions (Colombatto and Beauchemin, 2003; Tirado-González et al., 2016). Present study included random selected articles, some of them did not include information about the doses of $\mathrm{Cel}$ and Xyl supplemented according to the EA of products. Further systematic reviews should provide an analysis of the association between doses of EA and the degradability of DM and NDF.

\section{Conclusions}

The present systematic review showed high variability among treatments and studies. However, EFE supplementation consistently improved the NDFD, ADFD and DMD, although the type of EFE (Cel or Xyl) and the FP interacted: Xyl and Cel improved milk yield, milk protein and fat content, while adding EFE to diets with $\mathrm{FP} \geq 40 \%$ increased the ADG, but on grass-based diets EFE had the best effects on OMD and DMI. Since DMD, NDFD and ADFD were correlated with milk yield $(r>0.64)$, and DMD and ADFD with ADG ( $\mathrm{r}=0.59$ for ADFD), the effects of EFE on digestibility were consistently associated with an improvement in milk and ADG yields.

\section{Acknowledgments}

We are grateful for the funding and technical support of the Universidad Autónoma Chapingo and Tecnológico Nacional de México (TecNM)/Instituto Tecnológico El Llano Aguascalientes (ITEL). All co-authors were involved in the collection, analysis, interpretation, discussion and writing of the present manuscript. The funding sources had no role in the present study. There are no conflicts of interest to declare.

\section{References}

A 1 maraz I., Segundo-González S., Pinos-Rodríguez J.M., Miranda L.A. (2010). Effects of exogenous fibrolytic enzymes on in sacco and in vitro degradation of diets and on growth performance of lambs. Ital. J. Anim. Sci., 9: 6-10.

A ls ersy H., Salem A.Z.M., B orhami E., Olivarles J., Gado H.M., Mariezcurrena M.D., Yacuot M.H., Kholif A., El-Adawi M., Hermández S. (2015). Effect of Mediterranean saltbush (Atripelx halimus) ensiling with two developed enzyme cocktails on feed intake, nutrient digestibility and ruminal fermentation sheep. Anim. Sci. J., 86: 51-58.

Álvarez G., P in os - R odríguez J.M., Herrera J.G., García J.C., González S.S., Bárc e n a R. (2009). Effects of exogenous fibrolytic enzymes on ruminal digestibility in steers fed high fiber rations. Livest. Sci., 121: 150-154.

Arriola K.G., Kim S.C., Staples C.R., Ades ogan A.T. (2011). Effect of fibrolytic enzyme application to low- and high- concentrate diets on the performance of lactating dairy cattle. J. Dairy Sci., 94: 832-841.

Arriola K.G., Oliveira A.S., Ma Z.X., Giurcanu M.C., Adesogan A.T. (2017). A metaanalysis on the effect of dietary application of exogenous fibrolytic enzymes on the performance of dairy cows. J. Dairy Sci., 100: 4513-4527.

A s s ou ma y a C., B oval M., We is be cker J.L., S a minadin G., A r chiméde H. (2007). Limits of exogenous fibrolytic enzymes to improve digestion intake of a tropical grass. Asian-Austral. J. Anim. Sci., 20: 914-919. 
Avellaneda-Cevallos J.H., González-Muñoz S.S., Pinos-Rodríguez J.M., Hernández-Garay A., Montañez-Valdez O.D., Aya la J. (2007). Enzimas fibrolíticas exógenas en la digestibilidad in vitro de cinco ecotipos de Brachiaria. Agron. Mesoamericana, 18: $11-17$.

Avellaneda-Cevallos J.H., Pinos-Rodríguez J.M., González-Muñoz S.S., Bárcena R., Hernández-Garay A., Montañez-Valdez O. (2009). Effects of exogenous fibrolytic enzymes on ruminal fermentation and digestion of Guinea grass hay. Anim. Feed Sci. Technol., 149: 70-77.

Aw a w d e h M.S, O b e i d a t B.S. (2011). Effect of supplemental exogenous enzymes on performance finishing Awassi lambs fed olive cake-containing diets. Livest. Sci., 138: 20-24.

B a ah J., Shelfrod J.A., Hristov A.N., Mc Allister T.A., Cheng K.J. (2005). Effects of Tween 80 and fibrolytic enzymes on ruminal fermentation and digestibility of feeds in Holstein cows. Asian-Austral. J. Anim. Sci., 18: 816-824.

B a la P., M a li k R., S r in iv a s B. (2009). Effect of fortifying concentrate supplement with fibrolytic enzymes on nutrient utilization, milk yield and composition in lactating goats. Anim. Sci. J., 80: 265-272.

Balci F., Dikmen S., Gencoglu H., Orman A., Turkmen I.I., B iricik H. (2007). The effect of fibrolytic exogenous enzyme on fattening performance of steers. Bulga. J. Vet. Med., 10: $113-118$.

B a s s ioun i M.I., Ga far H.M., Saleh M.S., Mohi El D in A.M., Elshora M.A. (2011). Evaluation of rations supplemented with fibrolytic enzyme on dairy cows performance 2. In situ ruminal degradability of rations containing different roughages at two concentrate to roughage ratios. Researcher, 3: 21-33.

B e a u chemin K.A., Colombat to D., Morgavi D.P., Yang W.Z. (2003). Use of exogenous fibrolytic enzymes to improve feed utilization by ruminants. J. Anim. Sci., 81: E37-E47.

B e a u ch e m in K., Kr e u z e r M., O ' M a r a F.O., M c A 11 i s t e r T.A. (2008). Nutritional management for enteric methane abatement: A review. Aust. J. Exp. Agric., 48: 21-27.

B ilik K., Niwinska B., Lopuszanska-Rusek M. (2009). Effect of adding fibrolytic enzymes to periparturient and early lactation dairy cow diets on production parameters. Ann. Anim. Sci., 9: 401-413.

B o onthep K., Ngampongsai W., Wattanachant C., Visessanguan W., Boonpay ung S. (2011). Effects of enzyme levels in total mixed ration containing oil palm frond silage on kinetics of gas production. J. SAADC, 3: 563-567.

B ow $\mathrm{m}$ a n G.R., B e a u ch e m in K.A., S h e 1 ford J.A. (2002). In vitro degradation of fresh substrates treated with exogenous fibrolytic enzymes. Can. J. Anim. Sci., 82: 611-615.

C a no A.L., A randa I.E., Mendoza M.G., P ére z P.J., R a mos J.J. (2003). Comportamiento de toretes en pastos tropicales suplementados con caña de azúcar y enzimas fibrolíticas. Téc. Pecu. Méx., 41: 151-164.

Carréón L., Pinos-Rodríguez J.M., Bárcena S.S., Mendoza G. (2010). Influence of fibrolytic enzymes on ruminal disappearance and fermentation in steers fed diets with short and long particle length of forage. Ital. J. Anim. Sci., 9: 83-87.

Chaj i M., Moham ma d ab a d T. (2010). The effect of low temperature steam, sodium hydroxide and exogenous enzyme on in vitro degradation of rice straw by rumen bacteria of sheep. In. J. Small Rumin., 16: 190-194.

Chung Y.H., Zhou M., Holtshausen L., Alexander T.W., McAllister T.A., Guan L.L., Ob a M., B e a u chemin K.A. (2012). A fibrolytic enzyme additive for lactating Holstein cow diets: ruminal fermentation, rumen microbial populations, and enteric methane emissions. J. Dairy Sci., 95: 1419-1427.

Colo mbat to D., B e a c h e min K.A. (2003). A proposed methodology to standardize the determination of enzymic activities present in enzyme additives used in ruminant diets. Can. J. Animal Sci., 83: 559-568.

Colombat to M., Morgavi D.P., Furtado A.F., B e a c chem in K.A. (2003 a). Screening of exogenous enzymes for ruminant diets: relationship between biochemical characteristics and in vitro ruminal degradation. J. Anim. Sci., 81: 2628-2638.

Colombat to D., Mould F.L., Bhat M.K., Morgavi D.P., B e a u chemin K.A., Owen E. 
(2003 b). Influence of fibrolytic enzymes on the hydrolysis and fermentation of pure cellulose and xylan by mixed ruminal microorganisms in vitro. J. Anim. Sci., 81: 1040-1050.

Colo m b a t to D., Mould F.L., B hat M.K., Ow en E. (2006). Influence of exogenous fibrolytic enzyme level and incubation $\mathrm{pH}$ on the in vitro ruminal fermentation of alfalfa stems. Anim. Feed Sci. Technol., 137: 150-162.

Cruyw a ge n C.W., Z y l W.H. (2007). Effects of a fungal enzyme cocktail treatment of high and low forage diets on lamb growth. Anim. Feed Sci. Technol., 145: 151-158.

De Souza M.A., Figueiredo V.P., B erchielli T.T., Nunes P.I., Soares G.J. (2006). Eficiëncia de síntese microbiana e atividade enzimática em bovinos submetidos à suplementação com enzimas fibrolíticas. Rev. Bras. Zootec., 35: 1194-1200.

De Souza M.A., Figue iredo V.P., Teresinha B.T., Nun es P.I. (2008)). Degradacao ruminal da silagem de milho e da palha de arroz utilizando enzimas fibrolíticas exógenas. Maringá, 30: 435-442.

D e a n D.B., A d e s o g a n A.T., K ru e g e r N.A., L i t t e 11 R.C. (2008). Effects of treatment with ammonia or fibrolytic enzymes on chemical composition and ruminal degradability of hays produced from tropical grasses. Anim. Feed Sci. Technol., 145: 68-83.

D e hghani M.R., We i s b erjg M.R., Hvelplund T., Krist en s en N.B. (2012). Effect of enzyme addition to forage at ensiling on silage chemical composition and NDF degradation characteristics. Livest. Sci., 150: 51-58.

D í a z A., Ranilla M.J., G ir a ld o L.A., Tej i d o M.L., C arro M.D. (2015) Treatment of tropical forages with exogenous fibrolytic enzymes: Effects on chemical composition and in vitro rumen fermentation. J. Anim. Phys. Anim. Nutr., 99: 345-355.

E 1 ghandour M.M.Y., Kholif A.E., Hermández J., Mariezcurrena M.D., López S., C a m a c ho L.M., Már qu e z O., S a le m A.Z.M. (2016). Influence of the addition of exogenous xylanase with or without pre-incubation on the in vitro ruminal fermentation of three fibrous feeds. Czech. J. Anim. Sci., 61: 262-272.

Elwakeel E.A., Titgemeyer E.C., Johnson B.J., Armendariz C.K., Shirley J.E. (2007). Fibrolytic enzymes to increase the nutritive value of dairy feedstuffs. J. Dairy Sci., 90: 5226-5236.

E u n J.S., B e a u c h e m in K.A. (2007 a). Enhancing in vitro degradation of alfalfa hay and corn silage using feed enzymes. J. Dairy Sci., 90: 2839-2851.

E un J.S., B e a u c h e m in K.A. (2007 b). Assessment of the efficacy of varying experimental exogenous fibrolytic enzymes using in vitro fermentation characteristics. Anim. Feed. Sci. Technol., 132: $298-315$.

Eun J.S., B e u chem in K.A. (2008). Assessment of the potential of feed enzyme additives to enhance utilization of corn silage fiber by ruminants. Can. J. Anim. Sci., 88: 97-106.

Eun J.S., B e a u chem in K.A., Hong S.H., B a u e r M.W. (2006). Exogenous enzymes added to untreated or ammoniated rice straw: Effects on in vitro fermentation characteristics and degradability. Anim. Feed Sci. Technol., 131: 86-101.

Eun J.S., B e a uchemin K.A., Schluze H. (2007 a). Use of exogenous fibrolytic enzymes to enhance in vitro fermentation of alfalfa hay and corn silage. J. Dairy Sci., 90: 1440-1451.

E un J.S., B e a u chem in K.A., S ch luze H. (2007 b). Use of an in vitro fermentation bioassay to evaluate improvements in degradation of alfalfa hay due to exogenous feed enzymes. Anim. Feed Sci. Technol., 135: 315-328.

F a c chin i F.D.A., Re is V.R.A., R o th A.P., Magalha es K.A. (2012). Peixoto-Nogueira SC, Casagrande DR, Reis RA, Polizeli ML. Effects of Aspergillus spp. exogenous fibrolytic enzymes on in vitro fermentation of tropical forages. J. Food Agric., 92: 2569-2573.

Flores C., Caja G., Cas als R., Albanell E., S uch X. (2008). Performance of dairy ewes fed diets with a fibrolytic enzyme product included in the concentrate during the suckling period. Animal, 2: 962-968.

Franco G.L., F erre ir a R.F., R o ch a M.T., C y s ne iros C.S., D i o g o J.M. (2008). Parametros ruminaris e desaparecimiento da matéria seca e fibra em detergente neutro da forragem em bovinos que recebendo levadura e enzimas fibrolíticas na dieta. Rev. Bras. Saúde Prod. Anim., 9: 488-496.

Ga do H.M., S a le m A.Z.M., R ob in s on P.H., Ha s s a n M. (2009). Influence of exogenous en- 
zymes on nutrient digestibility extent of ruminal fermentation as well as milk production and composition in dairy cows. Anim. Feed Sci. Technol., 154: 36-46.

G a d o H.M., S a le m A.Z.M., O d o n g o N.E., B or ha mi B.E. (2011). Influence of exogenous enzymes ensiled with orange pulp on digestion and growth performance in lambs. Anim. Feed Sci. Technol., 165: 131-136.

Ga d o H.M., A 1 mu s t a fa S.S., S a le m A.Z., K halil F.A., A b d a lla E.B. (2014). Influence of vitamins and exogenous enzymes combination on alleviating heat stress in lactating ewes under Egyptian summer conditions. Anim. Nutr. Feed Tech., 14: 195-203.

G a do H.M., Elgh and u r M.M.Y., Ci priano M., O d ong o N.E., S a l e m A.Z.M. (2017). Rumen degradation and nutritive utilization of wheat straw, corn stalks and sugarcane bagasse ensiled with multienzymes. J. Appl. Anim. Res., 45: 485-489.

Gallardo I., Bárcena R., Pinos-Rodríguez J.M., Cobos M., Carreón L., Orteg a M.E. (2010). Influence of exogenous fibrolytic enzymes on in vitro and in sacco degradation of forages for ruminants. Italian J. Anim. Sci., 9: 34-38.

Giraldo L.A., Carro M.D., Ranilla M.J., Tejido M.L. (2007 a). Influence of fibrolytic enzymes on in vitro methane production and rumen fermentation of a substrate containing $60 \%$ grass hay. Lives. Res. Rural Develop., 19: 185.

G ir a ld o L.A., R a n 11 a M.J., Te j i d o M.L., C a r r o M.D. (2007 b). Influence of exogenous fibrolytic enzymes and fumarate on methane production, microbial growth and fermentation in Rusitec fermenters. British J. Nutr., 8: 753-761.

Girald o L.A., Carro M.D., Ranill a M.J., Teji d o M.L., M o hamed A.H. (2007 c). In vitro ruminal fermentation of low-quality forages as influenced by the treatment with exogenous fibrolytic enzymes. Options Mediterranées A, 74: 263-267.

Giraldo L.A., Tejid o M.L., R anilla M.J., C arro M.D. (2008 a). Effects of exogenous fibrolytic enzymes on in vitro ruminal fermentation of substrates with different forage: concentrate ratios. Anim. Feed Sci. Technol., 141: 306-325.

Girald o L.A., Tejido M.L., Ranilla M.J., Ramos S., Carro M.D. (2008 b). Influence of direct-fed fibrolytic enzymes on diet digestibility and ruminal activity in sheep fed as grass haybased diet. J. Anim. Sci., 86: 1617-1623.

Góm ez - Vázquez A., M endonza-Martínez G., P inos-Rodríguez J. (2011 a). Comparison of in vitro degradation of elephant grass and sugarcane by exogenous fibrolytic enzymes. Afr. J. Microbiol. Res., 5: 3051-3053.

Gómez-Vázquez A., Mendonza-Martínez G., Aranda E., Pérez J., Hernández A., Pinos-Rodríguez J.M. (2011 b). Influence of fibrolytic enzymes on growth performance and digestion in steers grazing stargrass and supplemented with fermented sugarcane. J. Appl. Anim. Res., 39: 77-79.

Granzin B.C. (2005). Effects of a fibrolytic enzyme supplement on the performance of Holstein Friesian cows grazing kikuyu. Trop. Grasslands, 39: 112-116.

Gu er r a L.J.E., I b arra L.E., S o to A.L.E., Hernánd e z M.J.J.R., C orra le s A.J.L., R o d rí guez G.J., Lópe z J.L.A., Córdova-I zquierdo A. (2007). Alfalfa ruminal degradation using xylanases. J. Anim. Vet. Adv., 6: 1443-1445.

Hatfi eld R., Fuk u sh i m a R.S. (2005). Can lignin be accurately measured? Crop. Sci., 45: 832839.

Hernández A., Kholif A.E., Lugo-Coyote R., Elghandour M.M.Y., Cipriano M., R o dríg u e z G.B., O d ong o N.E., S a l e m A.Z.M. (2017 a). The effect of garlic oil, xylanase enzyme and yeast on biomethane and carbon dioxide production from 60-d old Holstein dairy calves fed a high concentrate diet. J. Clean. Prod., 148: 616-623.

Hernández A., Kholif A.E., Elghandour M.M.Y., Camacho L.M., Ci priano M.M., S a 1 e m A.Z.M., C r u z H., U g b o g u E.A. (2017 b). Effectiveness of xylanase and Saccharomyces cerevisiae as feed additives on gas emissions from agricultural calf farms. J. Clean. Prod., 148: $616-623$.

Holtshausen L., Chung Y.H., Gerardo-Cuervo H., Oba M., Beauchemin K.A. (2011). Improved milk production efficiency in early lactation dairy cattle with dietary addition of a developmental fibrolytic enzyme additive. J. Dairy Sci., 94: 899-907.

Hong S.H., L e e B.K., Cho i N.J., L e e S.S., Yung G., H a J.K. (2003). Effects of enzyme appli- 
cation method and levels and pre-treatment times on rumen fermentation, nutrient degradation and digestion in goats and steers. Asian-Aust. J. Anim. Sci., 16: 389-393.

Hristov A.N., M c Allister T.A., Cheng K.J. (2000). Intraruminal supplementation with increasing levels of exogenous polysaccharide-degrading enzymes: Effects on nutrient digestion in cattle barley grain diet. J. Anim. Sci., 78: 477-487.

Hristov A.N., B a sel C.E., Melgar A., Foley A.E., Ropp J.K., Hunt C.W., Tricaric o J.M. (2008). Effect of exogenous polysaccharide-degrading enzyme preparations on ruminal fermentation and digestibility of nutrients in dairy cows. Anim. Feed Sci. Technol., 145: 182-193.

H w a n g H.I., He e L.C., W o o K.S., Gu y n S.H., Young L.S., S i 11 L.S., Hong H., Kwak Y., H a J.K. (2008). Effects of mixtures of Tween 80 and cellulolytic enzymes on nutrient digestion and cellulolytic bacterial adhesion. Asian-Austral. J. Anim. Sci., 21: 1604-1609.

J a mi E., Mizrahi I. (2012). Composition and similarity of bovine microbiota across individual animals. Plos One, 7(3): e33306.

J e w e 11 K.A., M c Cormik C.A., O d t C.L., We i m e r P.J., S u en G. (2015). Ruminal bacterial community composition in dairy cows is dynamic over the course of two lactations and correlates with feed efficiency. Appl. Environ. Microbiol., 81: 4697-4710.

Jililvand G., Naserian A., Kebreab E., Od ong o N.E., Valizadeh R., Eftekhar F., L ó pe z S., F r a n c e J. (2008). Rumen degradation kinetics of alfalfa hay, maize silage and wheat straw treated with fibrolytic enzymes. Arch. Zootec., 57: 155-164.

J u n g H.G., C a s 1 e r M.D. (2006 a). Maize stem tissues: Cell wall concentration and composition during development. Crop Sci., 46: 1793-1800.

J u n g H.G., C a s 1 e r M.D. (2006 b). Maize stem tissues: Impact of development on cell wall degradability. Crop Sci., 46: 1801-1809.

$\mathrm{K}$ a $1 \mathrm{k}$ a n M., F i ly a I. (2011). Effects of cellulase enzyme on nutritive value, in vitro digestion characteristics and microbial biomass production on wheat straw. Kafkas Univ. Vet. Fak. Derg., 17: $585-594$.

Kholif A.E., Khattab H.M., El-Shewy A.A., Salem A.Z.M., Kholif A.M., El-Saye d M.M., Gad o H.M., Mar i e z curren a M.D. (2014). Nutrient digestibility, ruminal fermentation activities, serum parameters and milk production and composition of lactating goats fed diets containing rice straw treated with Pleurotus ostreatus. Asian-Austral. J. Anim. Sci., 27: 357-364.

Khol if A.E., E $1 \mathrm{~g} h$ and o u r M.M.Y., R od ríg u e z G.B., O $\mathrm{l}$ a f a d e h a n O.A., S a 1 e m A.Z.M. (2017) Anaerobic ensiling of raw agricultural waste with a fibrolytic enzyme cocktails as cleaner and sustainable biological product. J. Clean. Prod., 142: 2649-2655.

K n app J.R., L a u r G.L., Vad as P.A., We is s W.P., Tricarico J.M., (2014). Invited review: enteric methane in dairy cattle production: quantifying the opportunities and impact of reducing emissions. J. Dairy Sci., 97: 3231-3261.

Knowlton K.F., Taylor M.S., Hill S.R., Cobb S.R., Wilston K.F. (2007). Manure nutrient excretion by lactating cows fed exogenous phytase and cellulase. J. Dairy Sci., 90: 4356-4360.

K o z e lov L.K., I l i e v F., H irst o v A.N., Z a m a n S., M c All is t e r T.A. (2008). Effect of fibrolytic enzymes and an inoculant on in vitro degradability and gas production of low-dry matter alfalfa silage. J. Sci. Food Agric., 88: 2568-2575.

K ru e ger N.A., A d e s o g a A.T. (2008). Effects of different mixtures of fibrolytic enzymes on digestion and fermentation of bahiagrass hay. Anim. Feed Sci. Technol., 145: 84-94.

L e e H.J., J u n g J.Y., O h Y.K., L e e S.K., M a d s e n E.L., J e o n C.O. (2012). Comparative survey of rumen microbial communities and metabolites across one caprine and three bovine groups, using bar-coded pyrosequencing and ${ }^{1} \mathrm{H}$ Nuclear Magnetic Resonance Spectoscopy. App. Environ. Microbiol., 78: 5983-5993.

Li M., P en ner G.B., Hernán de z-S a n abri a E., O b a M., G u a n L.L. (2009). Effects of sampling location and time, and host animal on assessment of bacterial diversity and fermentation parameters in the bovine rumen. J. Appl. Micrbiol., 107: 1924-1934.

Li F., Thom as C.A., Chen Y., C re evey C.J., Guan L.L. (2019). Comparative metagenomic and metatranscriptomic analyses reveal the breed effect on the rumen microbiome and its association with feed efficiency in beef cattle. Microbiome, 7: 1-21. 
López-Aguirre D., Hernández-Meléndez J., Rojo R., Sánchez-Dávila F., López-Villa lobos N., S a lem A.Z.M., Vázquez-Armijo F., Ruíz S. (2016 a). Effects of exogenous enzymes and application method on nutrient intake, digestibility and growth performance of Pelibuey lambs. Springer Plus, 5:1399.

López-Aguirre D., Hernández-Meléndez J., Rojo R., Sánchez-Dávila F., Lóp ez-Villa lobos N., S a le m A.Z.M., Vázquez-Armijo F., Ruíz S., Jo a qu in S. (2016 b). In vitro gas production kinetics and degradability of a diet for growing lambs: effect of fibrolytic enzyme products at different dose levels. It. J. Anim. Sci., 15: 453-460.

L o p u s z a n s k a - R u s e k M., B i li k K. (2011). Influence of pre and postpartum supplementation of fibrolytic enzymes and yeast culture, or both, on performance and metabolic status of dairy cows. Ann. Anim. Sci., 11: 531-545.

Malik R., B andla S. (2010). Effect of source and dose of probiotics and exogenous fibrolytic enzymes (EFE) on intake, feed efficiency, and growth of male buffalo (Bubalus bubalis) calves. Trop. Anim. Health Prod., 42: 1253-1269.

Márquez A., Mendoza G., Pinos-Rodríguez J.M., Zavaleta H., González S., B untinx S., L o e r a O., Meneses M. (2009). Effect of fibrolytic enzymes and incubation $\mathrm{pH}$ on in vitro degradation of NDF extracts of alfalfa and orchardgrass. It. J. Anim. Sci., 8: 221-230.

M c A 11 is t e r T.A., S t a n ford K., B a e H.D., Tre a c h e r R.J., H r is t ov A.N., B a a h J., S h e 1 ford J.A., Cheng K.J. (2000). Effect of surfactant and exogenous enzymes on digestibility of feed and on growth performance and carcass traits of lambs. Can. J. Anim. Sci., 80: 35-44.

Mille r D.R., E11 i o t R., N ort o n B.W. (2008 a). Effects of an exogenous enzyme, Roxazyme G2 liquid, on digestion and utilization of barley and sorghum grain-based diets by ewe lambs. Anim. Feed Sci. Technol., 140: 90-109.

Mille r D.R., E 11 i o t t R., N o r t o n B.W. (2008 b). Effects of an exogenous enzyme, Roxazyme G2, on intake, digestion and utilization of sorghum and barley grain-based diets by beef steers. Anim. Feed Sci. Technol., 145: 159-181.

Mille r D.R., Granzin B.C., E 11 i o t R., N or to n B.W. (2008 c). Effect of an exogenous enzyme Roxazyme G2 liquid, on milk production in pasture fed dairy cows. Anim. Feed Sci. Technol., 145: 194-208.

Miranda-Romero L.A., Tirado-González D.N., Tirado-Estrada G., A méndola- Mas siotti R., Sandoval-González L., Ra mírez-Valverde R., S a lem A.Z.M. (2020). Quantifying non-fibrous carbohydrates, acid detergent fiber and cellulose of forage through an in vitro gas production technique. J. Sci. Food Agr., 100: 3099-3110.

M o harrery A., H v e l p lund T., We is b j erg M.R. (2009). Effect of forage type, harvesting time and exogenous enzyme application on degradation characteristics measured using in vitro technique. Anim. Feed Sci. Technol., 153: 178-192.

Moher D., Liberati A., Tetzlaff J., A $1 \mathrm{tm}$ an D.G. (2009). Preferred reporting items for systematic reviews and meta-analyses: The PRISMA statement. PLoS Med., 6: e1000097.

Morgavi D.P., Kelly W.J., Janssen P.H., A ttw ood G.T. (2013). Rumen microbial (meta) genomics and its application to ruminant production. Animal, 7:194-201.

Mors y T.A., Kholif A.E., Khol if S.M., Kholif A.M., S un X., S a le m A.Z.M. (2016). Effects of two enzyme feed additives on digestion and milk production in lactating Egyptian buffaloes. Ann. Anim. Sci., 16: 209-222.

M u w a 11 a M.M., H a d d a d S.G., Hi j a ze e n M.A. (2007). Effect of fibrolytic enzyme inclusion in high concentrate fattening diets on nutrient digestibility and growth performance of Awassi lambs. Livest. Sci., 11: 255-258.

N s e re ko V.L., B e a c chemin K.A., Morgavi D.P., Rode L.M., Furtado A.F., Mc A 1 li s t e r T.A., I w a a s A.D., Yang W.Z., Wang Y. (2002). Effect of a fibrolytic enzyme preparation from Trichoderma longibrachiatum on the rumen microbial population of dairy cows. Can. J. Microbiol., 48: 14-20.

$\mathrm{O}$ b a M., A 11 e n M. (1999). Evaluation of the importance of the digestibility of NDF from forage: Effects on dry matter intake and milk yield of dairy cows. J. Dairy Sci., 82: 589-596.

O b a M., A 11 en M. (2000 a). Effects of brown midrib 3 mutation in corn silage on productivity of dairy cows fed two concentrations of dietary neutral detergent fiber. 1 . Feeding behavior and nutrient utilization. J. Dairy Sci., 83: 1333-1341. 
O b a M., A 11 en M. (2000 b). Effects of brown midrib 3 mutation in corn silage on productivity of dairy cows fed two concentrations of dietary neutral detergent fiber. 2. Digestibility and microbial efficiency. J. Dairy Sci., 83: 1350-1358.

$\mathrm{O}$ b a M., A 11 e n M. (2005). In vitro digestibility of forages. Proc. Tri-State Dairy Nutrition Conference. Dep. Dairy Sci. The Ohio State University, Columbus, Ohio, 43210, pp. 81-91.

Petri R.M., F orster R.J., Yang W., M c K innon J.J., Mc A 11 is ter T.A. (2012). Characterization of rumen bacterial diversity and fermentation parameters in concentrate fed cattle with and without forage. J. App. Microbiol., 112: 1152-1162.

Pinos-Rodríguez J.M., González M.S.S., Mendoza M.G., Bárcena G.R., Cob o s P.M. (2001). Efecto de enzimas fibrolíticas glucosiladas en la digestibilidad in vitro de la MS y MO de alfalfa (Medicago sativa) y ballico (Lolium perenne). Rev. Científica FCV-LUZ, 11: 505-509.

Pinos-Rodríguez J.M., González M.S.S., Mendoza M.G., Bárcena G.R., Cobos P.M., Hernández A., Ortega E. (2002). Effect of exogenous fibrolytic enzyme on ruminal fermentation and digestibility alfalfa and rye-grass hay fed to lambs. J. Anim Sci., 80: 3016-3020.

Pinos-Rodríguez J.M., Moreno R., González S.S., Robinson P.H., Mendoza G., Álvarez G. (2008). Effects of exogenous fibrolytic enzymes on ruminal fermentation and digestibility of total mixed rations fed to lambs. Anim. Feed Sci. Technol., 142: 210-219.

Ranilla M.J., Tej i d o M.L., Girald o L.A., Tricári c o J.M., Ca r ro M.D. (2008). Effects of an exogenous fibrolytic enzyme preparation on in vitro ruminal fermentation of three forages and their isolated cell walls. Anim. Feed Sci. Technol., 145: 109-121.

Reboucas S., Nus sio L.G., Paziani S.F., Pedroso A.F., Mari L.J., Ribe iro J.L., Zopolla t to M., S c hmidt P., Junque ir a M.C., P a c k e r I.U., C a m p o s F.P. (2005). Fibrolytic enzymes and dry matter content of tanzaniagrass silages on the ruminal parameters, ingestive behavior and nutrient digestion of bovine. Rev. Bras. Zootec., 34: 736-745.

S a 1 e m A.Z.M., H a s s a n A.A., K hali 1 M.S., G a d o H.M., A l s e r s y H., S i m b a y a J. (2012). Effects of sun-drying and exogenous enzymes on nutrients intake, digestibility and nitrogen utilization in sheep fed Atriplex halimus foliages. Anim. Feed Sci. Technol., 171: 128-135.

S a le m A.Z.M., Gado H.M., C olo mbatto D., Elghandour M.M.Y. (2013). Effects of exogenous enzymes on nutrient digestibility, ruminal fermentation and growth performance in beef steers. Livest. Sci., 154: 69-73.

Salem A.Z.M., Als ersy H., C a ma cho L.M., E1-Adawi M.M., Elghandour M.M., K hol if A.E., A 1 on s o M.U., Z a ra g o z a A. (2015 a). Feed intake, nutrient digestibility, nitrogen utilization, and ruminal fermentation activities in sheep fed Atriplex halimus ensiled with three developed enzyme cocktails. Czech. J. Anim. Sci., 60: 185-194.

S a le m A.Z.M., Buendía-Rodríguez G., Elghandour M.M., Mariezcurrena M.A., P eña F.J., P li e g o A.B., Ch a g y án J.C.V., C e rrillo M.A., R o dríguez M.A. (2015 b). Effects of cellulase and xylanase enzymes mixed with increasing doses of Salix babylonica extract on in vitro rumen gas production kinetics of a mixture of corn silage with concentrate. J. Integrative Agr., 14: 131-139.

Shabar S.K., Sas on G., Doron-Faigenboim A., Durman A., Yaacoby S., Berg Miller M.E., White B.A., Shterzer N., Mizrahi I. (2016). Specific microbiome-dependent mechanisms underlie the energy harvest efficiency of ruminants. Isme J., 10: 2958-2972.

Shekar C., Thakur S.S., Shelke S.K. (2010). Effect of exogenous fibrolytic enzymes supplementation on milk production and nutrient utilization in Murrah buffaloes. Trop. Anim. Health Prod., 42: 1465-1470.

Srinivas B., Chaturvedi O.H., Malik R., As gar M. (2008). Effect of enzyme to substrate ratio of exogenous fibrolytic and protease enzymes on in vitro gas production kinetics. In. J. Small Rum., 14: 181-190.

Sutton J.D., Phipps R.H., Deaville E.R., Jones A.K., Humphries D.J. (2002). Wholecrop wheat for dairy cows: effects of crop maturity, a silage inoculant and an enzyme added before feeding on food intake and digestibility and milk production. Anim. Sci., 74: 307-318.

Tang S.X., Tayo Z.L., Sun H., Shen L.X., Zhou C.S., Xia o W.J., Ren G.P., Han X.F., 
S h e n S.B. (2008). Effects of yeast culture and fibrolytic enzyme supplementation on in vitro fermentation characteristics of low-quality cereal straws. J. Anim. Sci., 86: 1164-1172.

Tirado-Estrada G., Mendoza M.G.D., Pinos-Rodríguez J.M., Quezada T.T., Guevara-Lara F. (2011). Effects of two fibrolytic enzyme mixture on growth performance, digestion and ruminal fermentation in lambs fed corn stover based diets. J. Appl. Anim. Res., 39: 158-160.

Tirado-González D.N., Jáuregui-Rincón J., Tirado-Estrada G., Martínez- Hernández P.A., Gu evara-Lara F., Miranda-Romero L.A. (2016). Production of cellulases and xylanases by white-rot fungi cultured in corn stover media form ruminant feed applications. Anim. Feed Sci. Technol., 221: 147-156.

Tirado-González D.N., Miranda-Romero L.A., Ruíz-Flores A., Medina-Cuéllar S.E., R a mírez-Va lverde R., Tirado-Estrad a G. (2018). Meta-analysis: effects of exogenous fibrolytic enzymes in ruminant diets. J. Appl. Anim. Res., 46: 771-776.

T it i H.H. (2003). Evaluation of feeding a fibrolytic enzyme to lactating dairy cows on their lactational performance during early lactation. Asian-Austral. J. Anim. Sci., 16: 677-684.

Vald é s K.I., S a le m A.Z.M., Ló pe z S., A 1 on s o M.U., Rive ro N., E 1 gh andour M.M.Y., Domínguez I.A., Ronquillo M.G., Kholif A.E. (2015). Influence of exogenous enzymes in presence of Salix babylonica extract on digestibility, microbial protein synthesis and performance of lambs fed maize silage. J. Agric. Sci., 153: 732-742.

Vallejo L.H., Sale m A.Z.M., Camacho L.M., Kholif A.M., Mariezcurrena M.D., Cipriano M., A lons o M.U., Olivares J., López S. (2016 a). Effects of xylanase supplementation on feed intake, digestibility and ruminal fermentation in Rambouillet sheep. J. Agricultural Sci., 154: 1110-1117.

Valle jo L.H., S a le m A.Z.M., Khol if A.E., Elghandour M.M.Y., F ajardo R.C., Rive ro N., B a stida A.Z., M arie z currena M.D. (2016 b). Influence of cellulase and xylanase on in vitro rumen gas production and fermentation of corn stover. Indian J. Anim. Sci., 86: 70-74.

Vallejo-Hernández L.H., Elghandour M.M.Y., Greiner R., Anale U.Y., Rivas - Cá c ere s R., B a rros-R odríguez M., S a l e m A.Z.M. (2018). Environmental impact of yeast and exogenous xylanase on mitigating carbon dioxide and enteric methane production in ruminants. J. Clean. Prod., 189: 40-46.

Wang Y., Mc A 11 is ter T., R od e L., B e a u chemin K., Morgavi D., N se re ko V., I wa a s a A., Yang W. (2002). Effects of exogenous fibrolytic enzymes on epiphytic microbial populations and in vitro digestion of silage. J. Sci. Food Agric., 82: 760-768.

Wang Y., McAllister T., Baah J., Wilde R., B eauchemin K.A., Rode L.M., She lfor d J.A., K a m a n d e G.M., C h e n g K.J. (2003). Effect of Tween 80 on in vitro fermentation of silages and interactive effects of Tween 80, monoensin and exogenous fibrolytic enzymes on growth performance by feedlot cattle. Asian-Austral. J. Anim. Sci., 16: 968-978.

Wang Y., S prat 1 ing B.M., Z o B e 11 D.R., Wi e d m e i e r R.D., M c A 11 i s t e r T.A. (2004). Effect of alkali pretreatment of wheat straw on the efficacy of exogenous fibrolytic enzymes. J. Anim. Sci., 82: 198-208.

Wang Y., Ramirez-B ribies c a J.E., Yanke L.J., Ts ang A., M c A 11 is te r T.A. (2012). Effect of exogenous fibrolytic enzyme application on the microbial attachment and digestion of barley straw in vitro. Asian-Austral. J. Anim. Sci., 25: 66-74.

Ware R.A., Torre n ter a N., Z in n R.A. (2005 a). Influence of maceration and fibrolytic enzymes on the feeding value of rice straw. J. Anim. Vet. Adv., 4: 387-392.

Ware R.A., Calderón J.F., C or o n a L., Z in n R.A. (2005 b). Case study: Comparative feeding value of rice straw in growing-finishing diets for calf-fed Holstein steers: Fibrolytic enzyme supplementation. Prof. Anim. Sci., 21: 416-419.

X u C., Wang H., Yang F., Yu Z. (2011). Effect of an inoculant and enzymes on fermentation quality and nutritive value of erect milkvetch (Astragalus adsurgens Pall.) silages. J. Anim. Feed Sci., 20: 449-460.

Yang H.E., S on Y.S., B e a u che m in K.A. (2011). Effects of exogenous enzymes on ruminal fermentation and degradability of alfalfa hay and rice straw. Asian-Austral. J. Anim. Sci., 24: 56-64.

Yu P., M c K in non J., Christen s e n D.A. (2005). Improving the nutritional value of oat hulls for ruminant animals with pretreatment of a multienzyme cocktail: in vitro studies. J. Anim. Sci., 83: 1133-1141. 
Zh ou X., S m i th J.A., O i F.M., K o e hl e r P.G., B e n n e t t G.W., S c harf M.E. (2007). Correlation of cellulase gene expression and cellulolytic activity throughout the gut of the termite Reticulitermes flavipes. Gene, 395: 29-39.

Zhou M., Hernández-S a n a bria E., Guan L.L. (2009). Assessment of the microbial ecology of ruminal methanogens in cattle with different feed efficiencies. App. Environ. Microbiol., 75: 6624-6633.

Received: 21 IX 2020

Accepted: 8 I 2021 